\title{
"CERTAIN FUNDAMENTAL TRUTHS": A DIALECTIC ON NEGATIVE AND POSITIVE LIBERTY IN HATE-SPEECH CASES
}

\author{
W. BRADLEY WENDEL*
}

INTRODUCTION

The following conversation between a civil libertarian and a new-left First Amendment theorist occurred as part of the ABA's conference on the present and future of the Bill of Rights. The discussion was precipitated by the case of Matthew Hale, a white supremacist who-to put it mildly-likes to attract media attention. He set himself up as the leader of a racist "church" called the World Church of the Creator, and immediately went about attempting to put an articulate, polite face on the organization, much in the way that David Duke tried to appear less threatening during his run for Congress in Louisiana. But there is only so much window-dressing that Hale can do, since he is obviously a rabid racist. His website contains numerous exhortations to "racial loyalty" and "racial holy war"; shopworn canards about blacks, Jews, and other ethnic minorities (called the "mud races" by Hale); a bizarre theology based on the "Sixteen Commandments" and vehement denunciations of Christianity; longdiscredited bogus biological theories about racial differences; and a boilerplate disclaimer that the group does not condone violence. ${ }^{1}$ Hale's little corner of cyberspace is representative of a burgeoning number of websites maintained by white supremacists and other hate groups. ${ }^{2}$ The World Church of the Creator site alone contains links to dozens of other racist sites, ${ }^{3}$ including those maintained by the Knights of the Ku Klux Klan, the American Nazi Party, and the

Copyright $@ 2002$ by W. Bradley Wendel

This article is also available at http://www.law.duke.edu/journals/65LCPWendel.

* Assistant Professor of Law, Washington and Lee University. This essay develops more fully some themes from an earlier work, W. Bradley Wendel, Free Speech for Lawyers, 28 HASTINGS CONST. L.Q. 305 (2001). A quite different version of this essay was awarded the 2001 Joe E. Covington Prize for scholarship in bar admissions topics by the National Conference of Bar Examiners and is published as W. Bradley Wendel, Hate and the Bar: Is the Hale Case McCarthyism Redux or a Victory for Racial Equality?, BAR EXAMINER, May 2001, at 26. I am grateful to Richard Delgado, Susan Gellman, Ron Krotoszynski, Adam Scales, and Barry Sullivan for their valuable comments, and to Rebecca Miles for her expert research assistance and editing.

1. World Church of the Creator, at http://www.rahowa.com (last visited October 12, 2001). "Rahowa" is Hale's acronym for "racial holy war."

2. E.g., Michel Marriot, Rising Tide: Sites Born of Hate, N.Y. TimES, Mar. 18, 1999, at G1; Pam Belluck, Hate Groups Seeking Broader Reach, N.Y. TiMES, Jul. 7, 1999, at A16. 2001).

3. World Church of the Creator, at http://www.rahowa.com/links.htm (last visited October 12, 
White Aryan Resistance. But Hale and his organization have certainly established a higher profile than other hate groups on the Internet, particularly with their efforts to market racism to children with a kids' website featuring whitesupremacist games and puzzles-fun for the whole family! ${ }^{4}$

Hale also happens to be a graduate of Southern Illinois University Law School. Because of the publicity he had managed to attract, Hale's application to become a licensed attorney in Illinois was a media event, and the decision of the character and fitness committee of the Illinois Supreme Court, declining to certify his fitness for admission, generated immediate controversy. ${ }^{5}$ Alan Dershowitz offered to represent Hale in his challenge to this order, an offer which, as far as I know, was not taken up. ${ }^{6}$ Hale petitioned for review by the Illinois Supreme Court. He was denied, ${ }^{7}$ and he then petitioned for certiorari in the U.S. Supreme Court, which he was again denied. ${ }^{8}$

The Hale case is important not only to lawyers who represent unpopular applicants for admission to practice law. It has broader significance as a test case for much of the recent theorizing about the application of the First Amendment to hateful expression. Hale's application to practice law also provides a wonderful illustration of how the new left critique of the First Amendment would play out in practice, since the Illinois bar committee swallowed the new left position hook, line, and sinker. The committee emphasized the constitutional values of racial equality and human dignity that were threatened by Hale's asserted expressive liberties and concluded that the value of equality must supersede the value of free speech.' This is exactly what some of the new left critics had been urging courts to do in hate-speech cases. ${ }^{10}$ For example,

4. World Church of the Creator Kids!, at http://www.wcotc.com/kids (last visited October 12, 2001). Activities include games like word scrambles (representative question: "cniioetxtn-Hint: This is what the White Race faces if we don't save it") and crossword puzzles (sample clue: "__ races are races that are not white"). The white supremacist organization "Stormfront" also has a kids' page, maintained by the twelve-year-old son of Stormfront's founder. See Stormfront White Pride World Wide, at http://www.stormfront.org (last visited October 12, 2001).

5. The full name of the body which initially denied Hale's application is the Committee on Character and Fitness for the Third Appellate District of the Supreme Court of Illinois (Inquiry Panel). The Inquiry Panel's decision is reprinted in GEOFFREY C. HAZARD, JR. ET AL., THE LAW AND ETHICS OF LAWYERING 875 (3d ed. 1999). For convenience I will refer to the version of the Inquiry Panel's opinion included in the Hazard casebook, using that book's pagination [hereinafter Hale Inq. Panel Op.]. The Inquiry Panel's decision was affirmed on a narrower ground by a Hearing Panel of the Character and Fitness Committee. That decision is reprinted in the Teacher's Manual to the Hazard casebook, but is not otherwise readily available to the public.

6. Bob Van Voris, Muddying the Waters: Illinois Racist's Free Speech Case is Complicated by His Arrest Record, NAT'L L.J., Feb. 21, 2000, at A1 (quoting Dershowitz); a St. Louis attorney, Robert Herman, also offered to represent Hale. George Anastaplo, Lawyers, First Principles, and Contemporary Challenges: Explorations, 19 N. ILL. U. L. REV. 353, 356-57 (1999) (reporting that a Jewish civil rights lawyer - a "true believer" in the First Amendment-had also offered to represent Hale).

7. Illinois Supreme Court Minute Order, M.R. 16075 (Nov. 12, 1999) (on file with author).

8. Hale v. Comm. on Character and Fitness of the Illinois Bar, 530 U.S. 1261(2000).

9. Hale Inq. Panel Op., supra note 5, at 881-82.

10. E.g., Brief of Amici Curiae National Black Women's Health Project in Support of Respondent, R.A.V. v. City of St. Paul, 505 U.S. 377 (1992), reprinted in 2 HATE SPEECH AND THE CONSTITUTION: The CONTEMPORARY DEBATE: RECONCILING FREEDOM OF EXPRESSION AND EQUALITY OF CiTIZENSHIP 197 (Steven J. Heyman ed., 1996). 
Mari Matsuda, one of the pioneers of the critical race theory movement and the new left critique of the First Amendment, has suggested carving out an admittedly content-based, sui generis category of racist speech that can be regulated by the state. ${ }^{11}$ Charles Lawrence, another scholar of central importance to the progressive critics, proposes a more realistic, less categorical jurisprudence, in which constitutional values of racial equality and human dignity are given pride of place alongside the expressive liberties secured by the First Amendment. ${ }^{12}$ Again, this is precisely the suggestion adopted by the Illinois bar committee, which balanced the free-speech rights asserted by Hale against the equality interests his admission would threaten, and found Hale's claims wanting.

The controversy that led up to the Hale bar-admission case also is one of the more prominent examples of "cyber-hate," a much-feared consequence of the rapid expansion of the Internet. There is little doubt that the case would not have attracted so much attention without Hale's enthusiastic embrace of technology. In the 1990s, the danger posed by racist speech seemed to loom larger in light of the unknown impact the Internet would have on the recruiting and message-dissemination efforts of white-supremacist groups. As it has turned out, the effectiveness of websites has been less than many had predicted, although e-mail and discussion groups still serve as communications and recruiting tools for hate groups. ${ }^{13}$ (The Internet also has not been the boon for civil liberties that some had forecasted. It has become a heavily regulated medium, like any other. ${ }^{14}$ ) For a short period of time, however, it appeared that the effects of hate speech would spread like wildfire beyond the geographic boundaries of the bigot's community into the wide-open realm of "cyberspace," a term that also began to crop up in First Amendment scholarship around this time. As computer networks continue to proliferate in the new millennium, we can expect new controversies over the peculiarities of the new medium as compared with other media, like newspapers, radio, and television, which have created wrinkles in free speech doctrine..$^{15}$ At the present time, however, the Internet has not warranted its own version of Red Lion, a decision that modified the regulatory structure of the news media to accommodate the limited nature of the television broadcast spectrum. ${ }^{16}$ Certainly the Hale case does not appear to be the vehicle for reconceptualizing the regulation of cyberspace, as distinct from media such as newspapers, billboards, and pamphlets. The Illinois bar

11. Mari J. Matsuda, Public Response to Racist Speech: Considering the Victim's Story, 87 MiCH. L. REV. 2320, 2357 (1989).

12. Charles R. Lawrence III, If He Hollers Let Him Go: Regulating Racist Speech on Campus, 1990 DUKE L.J. 431.

13. Southern Poverty Law Center, Reevaluating the Net, InTELligenCE REP., Summer 2001, at 54.

14. Neil Weinstock Netanel, Cyberspace 2.0, 79 TEX. L. REV. 447 (2000) (book review).

15. Red Lion Broad. Co. v. FCC, 395 U.S. 367 (1969).

16. Eugene Volokh, Freedom of Speech, Cyberspace, Harassment Law, and the Clinton Administration, 63 LAW \& CONTEMP. PROBS. 299, 302 (2000) ("[T]he words 'in cyberspace' in the phrase 'restrictions on free speech in cyberspace' are generally, in my view, not terribly significant; the medium by and large does not and should not affect the protection-or lack of protection-given to the content."). 
committee did not attach special significance to the fact that Hale's messages of hate were communicated on a website, instead of via leaflets or signs. ${ }^{17}$ Because he would have remained only a local nuisance, however, the committee may not have perceived the need to make a political statement by denying his application.

I chose to write this essay in dialogue form for several reasons: First, the format is an homage to the innovative methodology of some of the new left critics of First Amendment scholarship. There is considerable overlap between the new left critics and members of the critical race theory and feminist legal theory movements who have pioneered methods like first-person narratives and fictional conversations. ${ }^{18}$ These methods, and the controversy they have sparked, are part of the story of recent First Amendment scholarship. ${ }^{19}$ Second, this format captures the evolutionary nature of constitutional theory. The past two decades have witnessed the rise of the new left challenge to classic civil libertarian views about expressive liberties, particularly where hate speech is involved. The battle lines between civil libertarians and new left critics are becoming clearer, but no new settled position or new orthodoxy has emerged from the debate. Finally, the format of this essay reflects my belief that this is not a debate that can easily be settled. The civil libertarian and new left positions are grounded in conceptions of political morality that are fundamentally incompatible-negative and positive liberty, as the great historian of ideas Isaiah Berlin has termed them..$^{20}$ In light of the ongoing controversy in political theory over these two concepts of liberty, I thought it inappropriate here to write a dogmatic defense of either position. My hope is to present the opposing arguments as sympathetically as possible and let the reader decide which is the more persuasive.

17. Ironically, Hale's group seems comfortable with traditional media as well. His organization recently threatened an interracial couple with death by placing fliers into the Thrifty Nickel, a classified-ads newspaper that was distributed free at local stores. The flier denounced the "wedding of the blond White woman with the mongrel Filipino animal savage" and announced that "such actions must be punished by DEATH." Southern Poverty Law Center, For Hale, a Wedding Worthy of Death, INTELLIGENCE REP., Fall 2000, at 2.

18. E.g., Derrick Bell, And We Are Not Saved (1992); Patricia J. Williams, The AlCHEMY OF RACE AND RIGHTS (1991); the long-running Rodrigo Chronicles by Richard Delgado, beginning with Rodrigo's [First] Chronicle, 101 YALE L.J. 1357 (1992) (book review); and Matsuda, supra note 11. Although dialogues and narrative are often associated with critical-race scholars, others have used this form to good effect. One of the best recent examples is Arthur Isak Applbaum, Professional Detachment: The Executioner of Paris, 109 HARV. L. REV. 458 (1995). Two of Lon Fuller's classic works of jurisprudence are in the form of fictional narratives. Lon L. Fuller, The Problem of the Grudge Informer, in THE MORALITY OF LAW app. at 245 (rev. ed. 1969); Lon L. Fuller, The Case of the Speluncean Explorers, 62 HARV. L. REV. 616 (1949).

19. For critiques, some more sympathetic than others, of nontraditional forms of scholarship see, e.g., Richard A. Posner, Nuance, Narrative, and Empathy in Critical Race Theory, in OvERCOMING LAW 368 (1995); Daniel A. Farber \& Suzanna Sherry, Telling Stories out of School: An Essay on Legal Narratives, 45 StAN. L. REV. 807 (1993); Randall L. Kennedy, Racial Critiques of Legal Academia, 102 HARV. L. REV. 1745 (1989).

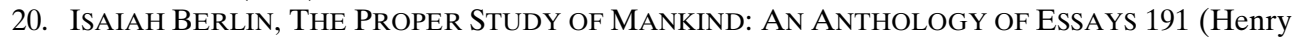
Hardy \& Roger Hausheer eds., Chatto \& Windus 1997). For convenience, I refer to page numbers in the version of the essay reproduced in Proper Study of Mankind and Isaiah Berlin, Two Concepts of Liberty (1958), reprinted in ISAIAH BERLIN, FOUR ESSAYS ON LIBERTY 118 (1969). 
One downside of the dialogue form is that most law professors are not very good playwrights, so these theoretical essays dressed up as conversations do not exactly read like Mamet. Doctrinal analysis in the form of fictionalized chitchat is also terribly artificial and tedious, like plot exposition as dialogue in a bad screenplay. There is not much I can do about these problems, except to stress that I am writing not for dramatic impact, but as a way to play two competing lines of argument against each other. (Unlike Derrick Bell and Richard Delgado, ${ }^{21}$ I am not concerned with creating believable fictional characters; the "speakers" here are just vehicles for presenting theoretical arguments.) Also, because I am assuming some familiarity with the hate-speech debate, I have tried to avoid lengthy exposition of the legal principles. My ambition here is to use this format to create something like a Hegelian dialectic, pushing the debate gradually deeper to reveal the political and theoretical assumptions of both sides, which are ultimately the thesis and antithesis of contemporary First Amendment theory. By setting out the history of free speech law in these terms, perhaps we can see the way clearly to a synthesis for the new millennium. Of course, if the reader judges one of the protagonists to have decisively refuted her opponent's arguments, then we have a thesis only, and are still awaiting an antithesis.

Another problem with writing a history of the hate-speech debate in the form of a dialogue is that it can be difficult to follow the argument as it moves from the doctrinal level through increasing degrees of theoretical complexity. I have tried to alleviate this problem somewhat by providing occasional headings where the discussion changes direction. But in order to take maximum advantage of the freedom offered by the dialogue format to roam widely through the practical and theoretical issues raised by this case, I do not adhere rigidly to these rough subject-matter divisions. Finally, in order to preserve some degree of narrative continuity, I do not begin with some of the classic arguments that each protagonist might be expected to mention. Some readers, for example, may be struck by the fact that the civil libertarian does not mention the state action doctrine (or the public/private distinction) until significantly later in the discussion. $^{22}$ I hope that considerations of readability justify deferring some of these doctrinal arguments to a natural place in the conversation.

The new left and civil libertarian arguments in this essay are amalgamations and are not intended to represent the views of any particular person. The civil libertarian position is so familiar that it practically writes itself, and I do not believe there will be much disagreement with the way it is formulated (as opposed to its correctness). ${ }^{23}$ What I refer to as the new left critic's arguments are an-

21. See supra note 18 and accompanying text.

22. See infra notes $167-173$ and accompanying text.

23. For some representative civil libertarian contributions to the recent debates on hate speech and pornography, see Charles Fried, The New First Amendment Jurisprudence: A Threat to Liberty, 59 U. CHI. L. REV. 225 (1992); Susan Gellman, Sticks and Stones Can Put You in Jail, But Can Words Increase Your Sentence? Constitutional and Policy Dilemmas of Ethnic Intimidation Laws, 39 UCLA L. REV. 333 (1991); Steven G. Gey, The Case Against Postmodern Censorship Theory, 145 U. PA. L. REV. 
other matter entirely. The group of scholars associated with progressive responses to civil libertarianism are quite diverse in their methodology, ideology, allegiances, and arguments, although there are, of course, broad areas of agreement. There is also, as mentioned above, much affinity between the new left critique of the standard civil libertarian First Amendment theory and allied movements such as critical legal studies, feminist legal theory, postmodernism, and especially critical race theory and outsider legal scholarship, although there are important differences among these groups. ${ }^{24}$ Some of the arguments below are influenced more by these general theoretical positions than by any argument specific to free speech issues. I have also tried to show linkages between the new left critique and more familiar jurisprudential positions, not to slight the contribution of outsider scholars to the development of the critique, ${ }^{25}$ but to show that although new left scholars are sometimes denounced as radicals, they have anchored their arguments in some deep objections to political liberalism that should be taken quite seriously. As a result of my method of bricolage, the arguments of the new left critic in this paper will probably not satisfy any actual member of this loosely defined group. ${ }^{26}$ That is as it should be, because the response to the well-entrenched civil libertarian viewpoint is still evolving, which makes the subject of hate-speech a good one for reviewing the recent history of the First Amendment and speculating about its future in the next millennium. The new left critic's arguments in this paper should be viewed as my idiosyncratic synthesis of diverse jurisprudential viewpoints, not as an attempt to essentialize any single scholar's or movement's position into the canonical statement of the progressive position.

We pick up with the civil libertarian ("CL") and the new left ("NL") critic talking about the Hale case.

\section{II}

\section{The Hale Case And Constitutional Doctrine}

CL: Sounds like a no-brainer to me. The committee got it wrong and the courts were wrong to deny review. The state's decision to deny Matthew

193 (1996); Gary Goodpaster, Equality and Free Speech: The Case Against Substantive Equality, 82 IOWA L. REV. 645 (1997).

24. The split between critical legal studies and critical race theory over the issue of rights is a significant and well-known example. See infra notes 112-13 and accompanying text. I also tend to rely more on critical race theory than feminist legal theory in formulating the new left position because the case under discussion involves racist expression. I do not intend to slight the contribution of feminist critics such as Andrea Dworkin and Catharine MacKinnon, who have contributed powerful critiques of conventional First Amendment theory in the context of pornography and sexual harassment. Because of the focus on the Hale case, however, I cannot spend too much time on the feminist arguments.

25. Cf. Richard Delgado, The Imperial Scholar Revisited: How To Marginalize Outsider Writing, Ten Years Later, 140 U. PA. L. REV. 1349 (1992).

26. And they may all object strenously to being supported by Ronald Dworkin! See infra notes 108-24 and accompanying text. Nevertheless, I believe there are significant unappreciated affinites between Dworkin's jurisprudence and some of the progressive critiques of the First Amendment. I do not suggest that any particular progressive scholars actually endorse these arguments. 
Hale a law license is a viewpoint-based restriction on expressive liberties. It is trying to punish him for having unpopular beliefs or saying things that offend some people. What possible basis does the state have for rejecting his application?

NL: Another no-brainer. Courts permit state bar associations (exercising their delegated powers ${ }^{27}$ ) to screen bar applicants for moral character. The standard is usually something like "the present ability and disposition of the applicant to practice law competently and honestly."28 The Hale case sounds outrageous only to someone who is unfamiliar with the pervasive regulation of lawyers' character that is a part of all states' baradmissions procedures. Applicants are denied permission to sit for the bar exam every day on the basis of conduct far less harmful than Hale's hatemongering. If an applicant's record reveals evidence of alcohol dependency, defaulting on student loans, lots of traffic tickets, academic dishonesty, or even impulse-control problems, forget about it. That person will not be permitted to sit for the bar. ${ }^{29}$ As a matter of constitutional law, how do you analyze those cases? Surely they are examples of viewpoint-based discrimination.

27. The bewildering variety of lawyers' professional associations can make it difficult to locate the state action necessary for an issue of constitutional law to arise. The court of last resort in a given state has the inherent power to regulate the practice of law by lawyers in that jurisdiction, and the state's highest court therefore has the authority to admit lawyers to practice and to administer a system of discipline for lawyers. (New York has, by statute, vested this authority in its four Appellate Divisions. See JUDICIARY LAW, NY CLS Jud $\S 90$ (2001).) Many bar associations are formally nothing more than trade associations, although numerous states have so-called "mandatory," "integrated," or "unified" bars, meaning that every lawyer who practices in that jurisdiction is required to belong to the bar association. Membership in the bar is made mandatory by order of the state's highest court. State bar associations and grievance committees exercise delegated powers originating with the state court, and are usually empowered to adopt rules governing lawyers' conduct, investigate allegations of misconduct, hold hearings, and make recommendations for appropriate discipline to the state court. See generally RESTATEMENT (THIRD) OF THE LAW GOVERNING LAWYERS $\S 1 \mathrm{cmts}$. c, d (2000); ABA/BNA LAWYERS' MANUAL ON PROFESSIONAL CONDUCT $§ 201: 101-03$; CHARLES W. WOLFRAM, MODERN LEGAL ETHICS $\S \S 2.2-2.3$ (practitioner's ed. 1986). Thus, in a case where a character and fitness committee of State X recommends against admission of a candidate, the denial of admission becomes a state action when it is approved by the state's highest court. In many, if not most, states this is a rubber-stamp procedure, so the decision is made for all practical purposes at the bar association level, even though it does not take on the character of state action until that decision is ratified by the court.

28. RESTATEMENT (THIRD) OF THE LAW GOVERNING LAWYERS $§ 2 \mathrm{cmt}$. d (2000).

29. E.g., In re Gossage, 5 P.3d 186 (Cal. 2000) (convicted murderer with a subsequent pattern of traffic and parking conviction); In re Mustafa, 631 A.2d 45 (D.C. 1993) (mishandling moot court funds); In re C.R.W., 481 S.E.2d 511 (Ga. 1997) (applicant defaulted on student loans and had filed two previous petitions for bankruptcy); In re Charles M., 545 A.2d 7 (Md. 1988) (lying in a deposition as a lay witness); In re Kapel, 651 N.E.2d 955 (Ohio 1995) (repeated traffic violations and psychiatric treatment for impulse control problems); In re Simmons, 584 N.E.2d 1159 (Ohio 1992) (misappropriation of funds from student organization); In re Roots, 762 A.2d 1161 (R.I. 2000) (applicant with convictions for shoplifting and resisting arrest, who had also published articles indicating "explicit racial and ethnic bias"); Unglaub v. Bd. of Law Exam'rs, 979 S.W.2d 842 (Tex. App. 1998) (applicant with history of alcohol abuse, but four years sober in AA; also had fallen behind on student loan payments); Frasher v. Bd. of Law Exam'rs, 408 S.E.2d 675 (W. Va. 1991) (applicant had three DUI convictions and 24 speeding tickets). 
CL: I thought the practice of screening out bar applicants for their "moral character" ended with the loyalty-oath cases. ${ }^{30}$ Isn't it true that the state can't ask an applicant questions like "are you or have you ever been a Communist"?

NL: Yes and no. You'd be surprised what the Supreme Court didn't decide in those cases. It is true that a state cannot refuse to admit an applicant who refuses to disclose membership in "subversive" organizations. ${ }^{31}$ On the other hand, the Court has permitted states to deny admission to a prospective lawyer who belonged to an organization that advocated violent overthrow of the United States where the applicant shared that specific intent. Moreover, the Court has permitted states to deny admission where the applicant refused to answer questions about whether he had that intent. ${ }^{32}$ Some states, like New York, continue to ask questions about membership in these organizations and sharing intent to use violent means against the government. ${ }^{33}$ I realize that these decisions are old, and that circumstances have changed. Justice Ginsburg has said that intervening cases, as well as the end of the Cold War, have cast doubt on the precedential value of the bar-admissions opinions, particularly since those cases were decided by a badly fractured Court. ${ }^{34}$ Until the Court overrules these decisions, however, they stand, and they provide a basis for denying admission to Hale.

CL: What basis? Those decisions weren't exactly the Court's finest hour. It will probably overrule them if it gets a chance, and they'll be consigned to the dustbin of First Amendment jurisprudence, joining all of those nowdiscredited opinions upholding convictions of Eugene Debs and antiwar protesters. ${ }^{35}$ Anyway, Hale has never admitted that he intends to commit illegal acts. In fact, he has said that he will work nonviolently within the legal system to bring about change, ${ }^{36}$ albeit change for the worse.

NL: Of course Hale can't be convicted of a crime for being a racist-unfortunately! But state bar associations make predictive judgments all the time concerning the potential that an applicant will be able to conduct himself or herself as a lawyer should. I'll give you an example that happened

30. E.g., Keyishian v. Bd. of Regents, 385 U.S. 589 (1967); United States v. Robel, 389 U.S. 258 (1967); Shelton v. Tucker, 364 U.S. 479 (1960); Beilan v. Bd. of Educ., 357 U.S. 399 (1958); Speiser v. Randall, 357 U.S. 513 (1958); Adler v. Bd. of Educ., 342 U.S. 485 (1952).

31. Baird v. State Bar of Ariz., 401 U.S. 1 (1971); Konigsberg v. State Bar of Cal., 366 U.S. 36 (1961); In re Anastaplo, 366 U.S. 82 (1961).

32. Law Students Civil Rights Research Council v. Wadmond, 401 U.S. 154, 164-66 (1971).

33. Colin A. Fieman, A Relic of McCarthyism: Question 21 of the Application for Admission to the New York Bar, 42 BUFF. L. REV. 47, 48 (1994).

34. Ruth Bader Ginsburg, Supreme Court Discourse on the Good Behavior of Lawyers: Leeway Within Limits, 44 DRAKE L. REV. 183, 189 (1996).

35. Gitlow v. New York, 268 U.S. 652 (1925); Debs v. United States, 249 U.S. 211 (1919); Schenck v. United States, 249 U.S. 47 (1919).

36. Hale Inq. Panel Op., supra note 5, at 876. 
right around the time of the Hale case. Picture this: A law student makes himself a gigantic pain in the neck for three years. ${ }^{37}$ He writes letters to local newspapers about school governance, puts up a nude photograph in his library carrel and threatens to sue when the school asks him to take it down, publicly accuses the dean of incompetence and corruption, files ethics complaints against the dean, writes stories about "corruption" in the university's health plan for the student newspaper, and, for his masterstroke, prints and sells "Deanie on a Weenie" T-shirts depicting a caricature of the dean "astride what appears to be a large hot dog." 38

CL: Perfect! That's exactly what lawyers are supposed to do. Investigating corruption, speaking out against an arrogant and distant administration, challenging the school to live up to its principles by precipitating a First Amendment battle over the nude photograph-that's great! "Deanie on a Weenie" may be juvenile, but it's certainly an effective form of protest. We need more lawyers like him. He was admitted, I take it.

NL: No, actually. The Nebraska Supreme Court unanimously upheld the state bar commission's recommendation that he be denied admission.

CL: That's outrageous!

NL: It's not out of line with the way lawyers' constitutional arguments are generally treated by courts. Remember that lawyers are "officers of the court" who have responsibility for conforming the conduct of individuals to the law. ${ }^{39}$ Sometimes the Supreme Court goes so far as to say that the ethical obligation of a lawyer is to ensure the reliability of the adversary system, not to interfere with its operation..$^{40}$ That's a rather statist vision of lawyering, I admit. But even some fairly libertarian Court decisions involving the law governing lawyers take pains to emphasize that the role of the lawyer is all about bringing clients into compliance with the law. ${ }^{41}$ There's a connection between the rule of law and the role of lawyers that just doesn't exist for other kinds of private speakers.

III

THE ILLINOIS BAR COMMITTEE'S ADOPTION OF THE NEW LEFT'S REASONING

CL: How does respecting the rule of law or being an officer of the court support denying admission to Matthew Hale? He has said that he will abide by all relevant substantive and procedural rules in his work as a lawyer.

\footnotetext{
37. In re Converse, 602 N.W.2d 500 (Neb. 1999).

38. Id. at 503-04.

39. E.g., Gentile v. State Bar of Nev., 501 U.S. 1030, 1056; 1075 (1991); In re Williams, 414 N.W.2d 394, 397 (Minn. 1987); Hallinan v. Comm. of Bar Exam'rs, 421 P.2d 76, 87 (Cal. 1966).

40. See Strickland v. Washington, 466 U.S. 668 (1984).

41. See Upjohn v. United States, 449 U.S. 383 (1981).
} 
NL: He refuses to accept the fundamental constitutional value of racial equality. ${ }^{42}$ There's no way he can work as a lawyer within our legal system if he refuses to acknowledge this principle. The Illinois Inquiry Panel simply resisted the First Amendment fetishism that courts seem unable to avoid and concluded that some fundamental constitutional values can be preferred to expressive liberties in some contexts. ${ }^{43}$ There are also equality values in the Constitution which are conveniently forgotten whenever the First Amendment is invoked. As for prospective lawyers, if they are not committed to a vision of professionalism that encompasses racial equality, it is better that we deny them admission at the outset.

CL: This is getting scary! If you permit the state to deny Hale a law license because he is a racist, you are allowing the government to function as the Thought Police. If you have good beliefs, you can be a lawyer; bad beliefs, you're out. Look, it's easy when it's a scuzzball like Matthew Hale. But think about all the other beliefs that are at odds with constitutional principles. Despite all the efforts of Scalia, Rehnquist, and friends, a woman still has a constitutional right to an abortion. Does that mean that a committed anti-abortion activist cannot become a lawyer because he or she does not assent to the "fundamental truth" of the right to choose? Or think about the death penalty. There are plenty of lawyers out there who believe the system of capital punishment is immoral and they are spending their careers resisting it. Would you deny them admission to the bar? Remember that anti-death-penalty arguments by lawyers aren't exactly favored in this political climate. The Supreme Court has been cutting back on habeas corpus for years, and Congress went even farther in 1996 with AEDPA. ${ }^{44}$ At some point, if it hasn't happened already, there will be a fundamental truth established that fast-tracked executions are a bedrock of our legal system. This isn't hypothetical. Remember, Senator McCarthy's crusade was also based on the incompatibility between Communism and the "fundamental truths" inherent in the American Constitution.

The whole point of the First Amendment is that the government doesn't get to choose up sides. You know the line from Barnette, "if there is any fixed star in the constitutional horizon it is that the government cannot prescribe what is orthodox in matters of belief." 45 It can't define "bad"

42. Hale Inq. Panel Opin., supra note 5, at 881.

43. Id. at 882. The Hale case is not the first time a connection has been suggested between racism and the character and fitness requirement for sitting for the bar. The faculty of a state law school responded to racist slurs that had appeared on school chalkboards by issuing a statement warning students that "racist, sexist, homophobic and anti-lesbian, ageist, and ethnically derogatory statements" might be construed as evidence that the student lacked "sufficient moral character to be admitted to the practice of law." Matsuda, supra note 11, at 2370 n.248.

44. Antiterrorism and Effective Death Penalty Act of 1996, Pub. L. No. 104-132, 110 Stat. 1214.

45. Bd. of Educ. v. Barnette, 319 U.S. 624 (1943). The full quotation is: "If there is any fixed star in our constitutional constellation, it is that no official, high or petty, can prescribe what shall be orthodox 
vs. "good" ideas and go around rewarding people who have good beliefs and punish those with bad beliefs.

NL: The state isn't seeking to regulate bad beliefs. It is denying a law license to a lawyer who has false beliefs about the value of racial equality in our legal system. In a case like that, the government can take sides, the dictum in Barnette notwithstanding. The state could fire a teacher who taught his geography class that the earth is flat, right? Or take a more controversial example. Could a school district mandate the teaching of evolution instead of "creation science" and fire a teacher who refused to comply with that guideline? I think you would say yes. ${ }^{46}$ And remember all of the government-speech cases where an employer is permitted to fire an employee whose speech is inconsistent with the employer's mission. Unless the employee is speaking out on a matter of public concern, she can be fired for substantially interfering with a government function, ${ }^{47}$ even if the "interference" is just publicly criticizing her employer. ${ }^{48}$

The government-employee speech cases are reinforced by the selectivefunding cases, like Rust v. Sullivan, ${ }^{49}$ which make it clear that the government can take a position on some issues. Think about it: The government can fund a public education campaign that says, "Wear your seatbelt," or "Quit smoking now," or "Don't have unprotected sex." It doesn't have to remain agnostic in public about whether or not wearing a seatbelt is a good idea. It can also, when setting up a judicial system, decide that rules of evidence are better than trial by ordeal. So why should the government, when it licenses lawyers, have to remain agnostic about whether lawyers can make it their life's work to harm people of color?

CL: I will grant you that the Court has held that there's nothing unconstitutional about funding decent but not indecent art, for example, ${ }^{.0}$ however, I think that decision is wrong, just as I thought Rust was wrong. But those cases are totally off point here. Matthew Hale is not a mouthpiece for the government. If anything, his role as a lawyer, if he could ever become one, ought to be understood as oppositional. We wouldn't want him to take the party line, so to speak, and for that reason this situation is nothing like the government-employee or selective-funding cases. Even though funding isn't an issue here, I think the practice of licensing law-

in politics, nationalism, religion, or other matters of opinion or force citizens to confess by word or act their faith therein." Id. at 642.

46. See Hazelwood Sch. Dist. v. Kuhlmeier, 484 U.S. 260 (1988); Bd. of Educ. v. Pico, 457 U.S. 853 (1982).

47. Connick v. Myers, 461 U.S. 138, 151 (1983) (citing Arnett v. Kennedy, 416 U.S. 134, 168 (1974)).

48. Waters v. Churchill, 511 U.S. 661, 681-82 (1994).

49. 500 U.S. 173 (1991) (upholding Health Department regulations limiting the ability of Title X fund recipients to engage in abortion-related activities).

50. Nat'l Endowment of the Arts v. Finley, 524 U.S. 569, 572-73 (1998). 
yers is like a state university handing out money to student organizations. The Court in Rosenberger said that, if a government entity makes financial assistance widely available to diverse speakers, it can't discriminate based on content in its allocation of funds. ${ }^{51}$ You can think of a license to practice law as "support" of some kind for expressive activities-here, the activity of taking a position on a legal issue.

Lawyers are different from the examples you cite. Lawyers are not state employees or conduits for government messages. They're private actors, hired by individuals, who oppose the state in many cases. ${ }^{52}$ That's what Charles Fried meant when he referred to the lawyer as the client's special-purpose friend, ${ }^{53}$ and it's an axiom of legal ethics that lawyers must be independent from state control so they can challenge the exercise of state power. $^{54}$ The Supreme Court has taken this position, too, in cases like NAACP v. Button, ${ }^{55}$ which reversed a Virginia Supreme Court decision holding that civil-rights lawyers had violated state rules on unlawful solicitation of clients by meeting with concerned parents to explain the ramifications of the Brown v. Board of Education ${ }^{56}$ decision and to offer to represent local plaintiffs in school-desegregation litigation. And, more recently, it distinguished the activities of government-funded legal aid lawyers from the medical advice given by doctors in $R u s t,{ }^{57}$ on the basis of the importance of an independent bar to the rule of law. ${ }^{58}$ The Court specifically noted that the legal services funding program was "designed to facilitate private speech, not to promote a governmental message." government-funded lawyers are intended to facilitate private speech, I just cannot see how a truly private lawyer, such as Matthew Hale intends to become, is more subject to content-based restrictions on his speech. Even if the state thinks racial equality is a good thing and wants to fund public-education campaigns to stamp out racism, it still has to permit racists to be lawyers (and lawyers to be racists). That's important because we do not want the state to declare a set of ideas off-limits to its

51. Rosenberger v. Rector of Univ. of Va., 515 U.S. 819, 842 (1995). See also Good News Club v. Milford Cent. Sch., 533 U.S. 98 (2001).

52. See Polk County v. Dodson, 454 U.S. 312 (1981) (holding that public defenders are not state actors for the purpose of a federal civil-rights statute).

53. Charles Fried, The Lawyer as Friend: The Moral Foundations of the Lawyer-Client Relation, 85 YALE L.J. 1060 (1976).

54. E.g., Monroe H. Freedman, Understanding Lawyers' Ethics (1990); Robert W. Gordon, The Independence of Lawyers, 68 B.U. L. REV. 1 (1988); John Mitchell, Reasonable Doubts Are Where You Find Them: A Response to Professor Subin's Position on the Criminal Lawyer's "Different Mission”, 1 GeO. J. LegAl ETHICs 339 (1987).

55. 371 U.S. 415 (1963). See also United Transp. Union v. State Bar of Mich., 401 U.S. 576 (1971); United Mine Workers v. Ill. State Bar Ass'n, 389 U.S. 217 (1967); Bhd. of R.R. Trainmen v. Virginia, 377 U.S. 1 (1964).

56. 347 U.S. 483 (1954).

57. Rust v. Sullivan, 500 U.S. 173 (1991).

58. See Legal Servs. Corp. v. Velazquez, 531 U.S. 533 (2001).

59. Legal Servs. Corp. v. Velazquez, 531 U.S. 533, 542 (2001). 
citizens. Individuals should have the liberty to think thoughts that the government doesn't like.

The abuse of liberty I'm worried about is not imaginary. Governments do not take kindly to speech at odds with their official beliefs. Recently, a court in Egypt sentenced a sociologist to seven years in prison for "defaming" Egypt by asking some uncomfortable questions about how free the country's elections are. ${ }^{60}$ And look what happens to U.S.-based Chinese scholars who are critical of the government: When they travel to China they just disappear, and presumably go away to rot in some prison. ${ }^{61}$

NL: This parade of horribles is a classic civil libertarian argument, but you know that slippery-slope arguments are never persuasive. ${ }^{62}$ It's always possible to draw principled distinctions. The NRA wants people to believe that, if we ban fully automatic assault rifles with sixty-shot clips full of armor-piercing ammunition, there's nothing stopping the government from kicking in doors and confiscating hunting rifles from law-abiding citizens. But there's a difference. You can regulate weapons that have no legitimate sporting or home-protective use-a principled distinction! The First Amendment works just like the Second. The principled distinction is found in the values of the legal system, including the fundamental value of racial equality. Expression that interferes with racial equality by contributing to the social construction of racism can be regulated in order to vindicate the Fourteenth Amendment Equal Protection Clause.

The point of my analogy with government speakers is that lawyers by their nature have an obligation to respect these legal values. Of course it's true that lawyers act on behalf of private interests, but they're heavily regulated by the state, and they have an ethical obligation to respect the law. Their willingness to abide by the rules makes the system work. Lawyers may not be state employees, but they're not purely private actors either. It's well settled that state court committees and bar associations can make predictive judgments about an applicant's fitness to practice law. If someone has embezzled moot court funds, it's more likely that she will steal from their clients, so the state can deny her a law license.

CL: Right, but notice the standards that bar associations use in this screening-competence and honesty. There's no First Amendment impediment to punishing dishonest lawyers, or keeping thieves out of the bar,

60. Neil MacFarquhar, Egypt Sentences Sociologist to 7 Years in Quick Verdict, N.Y. TIMES, May 22, 2001, at A6.

61. Anthony Kuhn, China Convicts Third Scholar Tied to U.S., L.A. TIMES, July 25, 2001, at A1; Craig S. Smith, Two Chinese Residents of U.S. Sentenced to Prison by Beijing, N.Y. TIMES, July 25, 2001, at A1.

62. See Frederick Schauer, Slippery Slopes, 99 HARV. L. REV. 361 (1985). 
just as the right to speak freely doesn't immunize someone from prosecution for criminal conspiracy. There also would have been no constitutional problem with denying admission to Hale for another prosaic reason: He was less than completely candid in his answers to the bar application. He had several arrests, as well as protective orders entered against him, and he didn't disclose them in response to questions on point. $^{63}$ As any law student who has had a professional responsibility course will tell you, failing to disclose anything, even something so minor as a speeding ticket, is an extremely serious matter to bar examiners and is frequently cited as the basis for denying admission on character and fitness grounds. ${ }^{64}$

NL: Those standards aren't content-neutral, though; they embody a particular vision of professionalism. The state reasons that a lawyer who doesn't disclose traffic tickets has personal values that are incompatible with the virtues of a lawyer. All I'm arguing is that being a white supremacist is surely more dangerous, from the standpoint of the effective functioning of the legal system, than telling a little white lie about speeding tickets on your bar application.

CL: No, those are different, because honesty is fundamental to the role of a lawyer.

NL: So is treating people with respect and dignity!

CL: In any event, the bar didn't go in that direction. For some reason, the committee members wanted to make a big show out of how committed they were to racial equality in the legal profession. Maybe they wanted to endorse the position that you folks have been advocating in law reviews. In any event, rejecting Hale for failing to disclose a protective order wouldn't have been much of a statement about how politically correct the Illinois bar is, so instead they came up with this baloney about certain fundamental constitutional values trumping the right to freedom of expression. As soon as the committee used Hale's refusal to profess the creed of racial equality, it became a case of Big Brother versus individual liberty. The government simply cannot be in the business of policing lawyers' political beliefs, or anyone else's.

NL: "Political beliefs" sounds so innocuous-like Illinois is excluding Hale because he's a Republican. But let's be straight on this guy's record. $\mathrm{He}$ is a dangerous individual who advocates violence against nonwhites. Just check out his website. He says things like: "It is the program of the

63. Van Voris, supra note 6. I am grateful to Bill Hodes for pointing out to me, and to other members of the LEGALETHICS listserv, this basis for denying Hale's application.

64. E.g., In re Gossage, 5 P.3d 186 (Cal. 2000) (discussing failure to disclose traffic and parking tickets as alternate ground for denying admission); Fla. Bd. of Bar Exam'rs re: N.R.W., 674 So. 2d 729 (Fla. 1996); In re DeBartolo, 488 N.E.2d 947 (Ill. 1986); In re Majorek, 508 N.W.2d 275 (Neb. 1993); In re Golia-Paladin, 472 S.E.2d 878 (N.C. 1996). 
Church of the Creator to keep expanding the White Race and keep crowding the mud races without necessarily engaging in any open warfare or without necessarily killing anybody." ${ }^{65}$ Yeah, sure, without "necessarily" killing anyone. But everyone knows he was behind the shooting spree of Benjamin Nathaniel Smith, who was trying to kill as many people of color and Jews as possible. ${ }^{66}$ This is a very dangerous organization we're talking about.

CL: If there's any First Amendment question that is well settled, though, it is whether the state can punish advocacy of violence absent a clear and present danger of imminent lawless action. The answer is clearly no. Hale can put anything he wants on his website, and it's almost certainly not going to violate Brandenburg. ${ }^{67}$

We've been down this road before. Remember the controversy about neo-Nazis demonstrating in Skokie, Illinois? ${ }^{68}$ I know you're probably sick to death of talking about that case, but I cannot see how it is distinguishable. The harm to the Holocaust survivors living in the town was real and direct-it was visceral terror and indescribable sorrow-but the court concluded that the Nazis' expressive liberties trumped the interest in protecting the town's residents from emotional trauma. However hurtful Hale's website is, it doesn't do anything like make someone relive Kristallnacht, the ghetto, and the death camps.

65. FAQ About Creativity, Question \#21, at http://www.rahowa.com/faq1 (last visited October 21, 2001) (emphasis added). See also id. at Question \# 24 ("Q: But wouldn't [the agenda of the group] mean the decline and perhaps the extermination of the colored races? A. Perhaps it would...."), Question \#29 ("Hitler's program was similar to what we are proposing.").

66. Bill Dedman, Midwest Gunman Had Engaged in Racist Acts at 2 Universities, N.Y. TIMES, July 6, 1999, at A1. See also Southern Poverty Law Center, The Great Creator, INTELLIGENCE REP., Summer 1999, at 23, 25-26 (detailing connections between Hale and Smith). Another follower of Hale's "church" was convicted of a hate crime for beating a Cuban-American man in Florida. See Associated Press Wire, Breaking News, White Supremacist Convicted, N.Y. TIMES ON THE WEB, at http://www. nytimes.com/apoline/a/AP-Racist-Attack.html (July 29, 1999). World Church of the Creator followers have also been convicted of other hate crimes, including the murder of a black sailor returning from the Gulf War in 1991, and the robbery and pistol-whipping of a store owner believed to be Jewish. See Belluck, supra note 2 .

67. Brandenburg v. Ohio, 395 U.S. 444 (1969).

68. See Collin v. Smith, 578 F.2d 1197 (7th Cir. 1978); see also DonAld ALEXANDER Downs, NAZIS IN SKOKIE: FREEDOM, COMMUNITY, AND THE FIRST AMENDMENT (1985); DAVID HAMLIN, The NAZi/SKokie Conflict: A CiVil Liberties BATtle (1980); ARYEH NeIER, Defending My

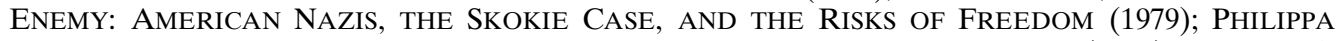
Strum, When the Nazis CAME to Skokie: Freedom fOr SPEeCh We Hate (1999); Lee C. Bollinger, The Skokie Legacy: Reflections on an "Easy Case" and Free Speech Theory, 80 MICH. L. REV. 617 (1982) (book review); David Goldberger, Skokie: The First Amendment Under Attack by Its Friends, 29 MERCER L. REV. 761 (1978). 
IV

\section{HATE SPEECH IN THE LEGAL SYSTEM}

NL: Maybe the Nazis can have a rally in front of the village hall in Skokie (although that was a crazy decision), but it does not follow that Hale can take Nazi-style positions as a lawyer. No lawyer has a First Amendment right to make frivolous arguments, have ex parte contacts with judges, introduce inadmissible evidence, or try to appeal to the prejudices of jurors. Why should Hale be allowed to pollute the legal system with his racism? This case is unlike Rosenberger, because the judicial system is not a public forum open to all speakers, like a college campus. That's why the state doesn't have to allow all viewpoints to be heard.

This isn't just about one insignificant kook named Matthew Hale. Racism and sexism are a big problem in the legal profession. I don't know where to begin listing the cases I've read involving hateful speech, such as a lawyer's characterization of his opponent's conduct at a deposition as "little sheeny Hebrew tricks"; 99 a bankruptcy lawyer's reference to a woman counsel for the United States trustee as "office help"; $;$ repeated references to an attorney as "little lady," "little mouse," "young girl," and "little girl"; $;$ and a prosecutor's comment that he did not believe "either one of those chili-eating bastards" who were defendants in a death penalty case. ${ }^{72}$ A state court judge in Illinois actually told a woman lawyer: "I don't think ladies should be lawyers. I believe you belong at home raising a family." ${ }_{33}$ One lawyer got so angry at his disqualification on the basis of a conflict of interest that he mailed a flyer to the prosecutor, who was a woman. The flyer read, "MALE LAWYERS PLAY BY THE RULES, DISCOVER TRUTH AND RESTORE ORDER. FEMALE LAWYERS ARE OUTSIDE THE LAW, CLOUD TRUTH AND DESTROY ORDER." ${ }^{\prime 4}$ Are you telling me that the First Amendment means that courts and state bar associations can't act to eliminate this kind of hurtful conduct by lawyers?

CL: Be careful of the context here. No one is saying that Hale should be allowed to wear white sheets in court and make references to the "mud races" at trial. Of course courts have the power to regulate the conduct

\footnotetext{
69. In re Williams, 414 N.W.2d 394, 397 (Minn. 1987).

70. In re Plaza Hotel Corp., 111 B.R. 882, 891-92 (Bankr. E.D. Cal. 1990).

71. Principe v. Assay Partners, 586 N.Y.S.2d 182, 184 (N.Y. Sup. Ct. 1992).

72. People v. Sharpe, 781 P.2d 659, 660 (Colo. 1989). The trial in this case was highly publicized and the comments resulted in the widespread perception that the prosecutor was biased against Latinos and was motivated by that prejudice to seek the death penalty.

73. Quoted in J. Cunyon Gordon, A Response from the Visitor from Another Planet, 91 MICH. L. REV. 1953, 1956 (1993).

74. United States v. Wunsch, 84 F.3d 1110, 1113 (9th Cir. 1996). The flyer was a copy of a headline from an article in California Lawyer magazine, which reported on negative gender-based stereotyping of female lawyers. Id. at 1113 n.1.
} 
of attorneys who practice before them. I'll accept that the courtroom is a non-public forum, where the government can impose content-based restrictions on speech, provided that it doesn't discriminate on the basis of viewpoint. ${ }^{75}$ The court can prevent a lawyer from making frivolous or irrelevant legal arguments that express positive or negative attitudes about various ethnic groups. For example, an African-American lawyer may be ordered to remove a Kente cloth tie because of the possibility that it might encourage the jury to decide the case on grounds unrelated to the merits. ${ }^{76}$ As long as the court applies that rule without regard to viewpoint, it is a permissible content-based regulation of speech in a nonpublic forum. You're right that Rosenberger doesn't apply to in-court speech.

What the Illinois court committee is doing is completely different, though. It wants to penalize Hale for his public expression, that is, for his speech in a public forum. Even public employees are free to speak out in public - think of a case like Pickering, where a schoolteacher wrote a letter to the editor criticizing the school board..$^{77}$ The First Amendment may even forbid dismissing an employee for statements made within the confines of the employer's premises, as long as they don't interfere with the work of the office. ${ }^{78}$ Even if Hale were a government lawyer, the context would be nothing like the arguable insubordination of Pickering or the spectacle of an employee of the sheriff's office expressing sympathy for someone who shot the President. A fortiori, the state cannot penalize a private actor for having obnoxious views and expressing them on his own time.

Denying Hale's law license because of his out-of-court white supremacy would be imposing an unconstitutional condition on the award of a government benefit or privilege. ${ }^{79}$ The government may not grant a benefit to a person on the condition that the recipient refrain from engaging in some constitutionally protected activity, even if the recipient is not entitled to the benefit in the first place ${ }^{80}$ For instance, a government agency may not deny a job to someone or dismiss an employee for belonging to "subversive" organizations, ${ }^{81}$ for refusing to take a loyalty oath, ${ }^{82}$ or for

75. Perry Educ. Ass'n v. Perry Local Educators Ass'n, 460 U.S. 37 (1983).

76. This illustration is taken from the case of John Harvey, a lawyer in the District of Columbia. Paul Butler, Racially Based Jury Nullification: Black Power in the Criminal Justice System, 105 YALE L.J. 677, 685 (1995); Patrice Gaines-Carter, D.C. Lawyer Told to Remove African Kente Cloth for Jury Trial, WASH. POST, May 23, 1992, at F1.

77. Pickering v. Board of Educ., 391 U.S. 563, 564 (1968).

78. See Rankin v. McPherson, 483 U.S. 378, 388-89 (1987) (holding that a clerical employee in the sheriff's office may not be dismissed for saying that, if another assassin took a shot at Ronald Reagan, "I hope they get him.").

79. See Kathleen M. Sullivan, Unconstitutional Conditions, 102 HARV. L. REV. 1415 (1989).

80. See Perry v. Sindermann, 408 U.S. 593, 597 (1972).

81. Keyishian v. Bd. of Regents, 385 U.S. 589 (1967). 
refusing to declare belief in God. ${ }^{83}$ The Court has extended the protection of the unconstitutional conditions doctrine to government contractors. Maybe there's a very rough analogy with lawyers, who exercise delegated powers from the state, and whose contracts may not be terminated for speaking out against the government or for refusing to support an elected official's campaign. ${ }^{84}$

You can also handle the issue of courtroom speech and private speech doctrinally by using the Supreme Court's "time, place, and manner" framework. ${ }^{85}$ A court could require that Hale take his racist speech outside, so to speak, and refrain from bringing up irrelevant matters during a trial. As long as the court's order leaves open alternative channels of communication (like Hale's website), is narrowly tailored to achieve a significant government interest (the interest in efficient and fair trials), and is viewpoint-neutral (it prevents both Hale and a black civil rights lawyer from referring to irrelevant matters), it is permissible. ${ }^{86}$

Not to pile on here, but I should probably mention that the Supreme Court has generally protected insulting or offensive speech. ${ }^{87}$ You think being called a "little mouse" is bad? Think about how you would feel if someone directed this diatribe at you:

\begin{abstract}
After God had finished the rattlesnake, the toad, and the vampire, He had some awful substance left with which He made a scab. A scab is a two-legged animal with a corkscrew soul, a water brain, a combination backbone of jelly and glue. Where others have hearts, he carries a tumor of rotten principles. When a scab comes down the street, men turn their backs and Angels weep in Heaven, and the Devil shuts the gates of hell to keep him out. No man (or woman) has a right to scab so long as there is a pool of water to drown his carcass in, or a rope long enough to hang his body with. Judas was a gentleman compared with a scab. For betraying his Master, he had character enough to hang himself. A scab has not. $^{88}$
\end{abstract}

The Court said that non-union letter carriers would just have to put up with being called scabs and getting described as disgusting, slithering

82. Wieman v. Updegraff, 344 U.S. 183 (1952).

83. Torcaso v. Watkins, 367 U.S. 488 (1961).

84. Bd. of County Comm'rs v. Umbehr, 518 U.S. 668 (1996); O’Hare Truck Serv., Inc. v. City of Northlake, 518 U.S. 712 (1996).

85. See, e.g., Hill v. Colorado, 530 U.S. 703 (2000); Ward v. Rock Against Racism, 491 U.S. 781 (1989); Clark v. Community for Creative Non-Violence, 468 U.S. 288 (1984); United States v. O’Brien, 391 U.S. 367 (1968).

86. The federal court of appeals decision holding that a state could not prohibit the Ku Klux Klan from "adopting" a stretch of highway to keep litter-free turned on the viewpoint discrimination inherent in the state's decision. Cuffley v. Mickes, 208 F.3d 702 (8th Cir. 2000). The state presumably would not have been averse to permitting the NAACP to adopt the same stretch of highway; thus, its decision to deny the KKK's request was motivated by disagreement with that organization's position.

87. E.g., United States v. Eichman, 496 U.S. 310, 319 (1990); Hustler Magazine v. Falwell, 485 U.S. 46, 55 (1988); Spence v. Washington, 418 U.S. 405, 412 (1974); Papish v. Univ. of Mo., 410 U.S. 667, 670 (1973); Cohen v. California, 403 U.S. 15 (1971); Street v. New York, 394 U.S. 576, 592 (1969).

88. Old Dominion Branch No. 496, Nat'l Ass'n of Letter Carriers v. Austin, 418 U.S. 264, 268 (1974). 
things. The words may hurt, but the Court called the passage from Jack London "merely rhetorical hyperbole" and "a lusty and imaginative expression of contempt," ${ }^{89}$ no different from any of the examples you just gave.

NL: I could give you counterexamples for every one of those rules you cite. Example number one: The unconstitutional conditions doctrine may not apply with the same force to the speech of lawyers. Take Justice Rehnquist's opinion in Gentile v. State Bar of Nevada, ${ }^{90}$ for example. He said quite clearly, quoting no less an authority than Justice Cardozo: "Membership in the bar is a privilege burdened with conditions." ${ }^{11}$ Lawyers in pending cases are subject to restrictions on speech to which an ordinary citizen would not be, Justice Rehnquist argued. ${ }^{22}$ He emphasized that even rights as fundamental as those guaranteed by the First Amendment may be subordinated to other interests that arise in litigation. $^{93}$ The reason for this subordination is the special status of a lawyer-she is an officer of the court, "an intimate and trusted and essential part of the machinery of justice." ${ }^{4}$

What you're objecting to is the old right/privilege distinction, the idea that a person who wishes to receive a government job may have a right to talk politics but no right to be a policeman, in the words of Holmes. ${ }^{95}$ The right/privilege distinction may be mostly a relic of the past in constitutional law generally, ${ }^{96}$ but it still has some force in lawyer-speech cases, as Justice Rehnquist's reasoning in Gentile shows.

Counterexample number two: You say that mere offense, like the reaction that a reader would have to the "scab" polemic, is never a legitimate basis for restricting speech. That may be the case, but courts have repeatedly held that some kinds of emotive harms are not "mere" offense. I could cite the Court's refusal to bring sexual harassment within the First Amendment, ${ }^{97}$ even though much of the harassment undoubtedly occurs

89. Id. at 286 .

90. 501 U.S. 1030 (1991).

91. Id. at 1066 (citing In re Rouss, 116 N.E. 782, 783 (N.Y. 1917)); see also People ex rel. Karlin v. Culkin, 162 N.E. 487, 489 (N.Y. 1928).

92. See Gentile, 502 U.S. at 1071.

93. See id. at 1073 (citing Seattle Times Co. v. Rhinehart, 467 U.S. 20 (1984) (holding that courts may issue protective orders limiting the dissemination of information obtained in discovery).

94. Id. at 1072 (quoting In re Sawyer, 360 U.S. 622, 668 (1959) (Frankfurter, J., dissenting)).

95. McAuliffe v. Mayor of New Bedford, 29 N.E. 517, 517 (Mass. 1892).

96. William Van Alstyne, The Demise of the Right-Privilege Distinction in Constitutional Law, 81 HARV. L. REV. 1439 (1968).

97. Harris v. Forklift Sys., Inc., 510 U.S. 17 (1993); Meritor Sav. Bank FSB v. Vinson, 477 U.S. 57 (1986); Kingsley R. Browne, Title VII as Censorship: Hostile-Environment Harassment and the First Amendment, 52 OHIO ST. L.J. 481 (1991); Cynthia L. Estlund, Freedom of Expression in the Workplace and the Problem of Discriminatory Harassment, 75 TEX. L. REV. 687 (1997); Suzanne Sangree, Title VII Prohibitions Against Hostile Environment Sexual Harassment and the First Amendment: No Collision in 
through the medium of speech, and I could try to distinguish the kind of harm resulting from being called a scab-no big deal, I'd assert-from the harm that results from having your whole dignity and worth called into question on account of an immutable characteristic like your race or sex. ${ }^{98}$ But instead I'll use an example closer to home-solicitation by lawyers. ${ }^{99}$ Even as the Court has significantly expanded the protection for commercial speech, practically erasing the line between commercial and non-commercial expression, ${ }^{100}$ it has permitted restrictions on lawyer solicitation to limit what?-offense, shock, and outrage caused by lawyers contacting accident victims. Sure, the Court said that the Florida regulation was not aimed at responding to pure emotive harms-rather it was concerned with "the demonstrable detrimental effects that such 'offense' has on the profession" ${ }^{101}$-but it's clear that the state was targeting offensive speech. It even admitted as much when it said that " $[\mathrm{t}]$ he purpose of the thirty-day targeted direct-mail ban is to forestall the outrage and irritation with the state-licensed legal profession that the practice of direct solicitation only days after accidents has engendered." ${ }^{102}$

You can read the Florida Bar case one of two ways, either of which supports my argument. One, the Court is not being entirely truthful when it says that emotive harms can never be the basis for restricting speech. Some kinds of emotive harms do indeed justify regulation; the only question is which ones those are. Once we admit that the harm from being solicited by lawyers soon after an accident is a legitimate basis for controlling lawyers' speech, then a civil libertarian such as yourself has to explain why that harm justifies limitations on speech, but the harm caused by a virulent racist such as Matthew Hale does not. Hale's speech is not "merely" offensive in the way that, say, George Carlin's Seven Dirty Words routine ${ }^{103}$ or the famous "Fuck the Draft"104 jacket is offensive. It is hurtful, evil, dangerous, demeaning, intimidating, and horrific. Please don't trivialize it by calling it "offensive." 105

The second possible reading of the Florida Bar case trades on what I call "lawyer exceptionalism"- the claim I mentioned earlier, that lawyers have such an intimate relationship with the rule of law that they are not

Sight, 47 Rutgers L. ReV. 461 (1995); Eugene Volokh, What Speech Does "Hostile Work Environment” Harassment Law Restrict?, 85 GEO. L.J. 627 (1997).

98. See Richard Delgado \& Jean Stefancic, Must We Defend NaZis?: Hate Speech, PORNOGRAPHY, AND THE NEW FIRST AMENDMENT (1997).

99. See Fla. Bar v. Went For It, Inc., 515 U.S. 618 (1995).

100. See, e.g., Greater New Orleans Broad. Assoc. v. United States, 527 U.S. 173 (1999); Rubin v.

Coors Brewing Co., 514 U.S. 476 (1995); Edenfield v. Fane, 507 U.S. 761 (1993).

101. Fla. Bar, 515 U.S. at 631.

102. Id.

103. FCC v. Pacifica Found., 438 U.S. 726 (1978).

104. Cohen v. California, 403 U.S. 15 (1971).

105. Lawrence, supra note 12 , at 461. 
purely private speakers. Their speech can be limited along lines analogous with government actors because, in a sense, they embody and defend the law itself. And because the law contains few values that are as significant as racial equality, applicants to the bar can be turned down if they refuse to respect that value. (Certainly racial equality is more important than the freedom from having to read a direct-mail solicitation from a lawyer!) You need to appeal either to lawyer exceptionalism or to some kind of unique emotional injury in order to explain the difference between the Florida Bar case, in which the Court held that lawyers may be prohibited from making direct contact with potential clients, and the Edenfield case, in which the Court reached precisely the opposite conclusion with respect to certified public accountants.

\section{$\mathrm{V}$ \\ THE CRITIQUe OF VALUE-NEUTRALITY}

NL [cont'd]: For the sake of argument, though, I will admit that you may be right as a matter of constitutional doctrine, but that's just the point. The civil-libertarian mindset is so entrenched that we have lost our ability to see anything wrong with it. We're so captivated by Mill's marketplace of ideas metaphor that we have abdicated our faculty of making moral judgments. Are we really going to accept that Matthew Hale is just another voice in the public debate and that we have to listen to him ranting about "mud races" and praising Hitler because, for all we know, he could be right? This kind of radical moral and epistemological skepticism is baseless. Come on, why don't we just admit that there is no value whatsoever to Hale's speech? That's what the Illinois court committee did when it said that lawyers must be committed to certain fundamental truths about the rule of law and racial equality, and if they are not, they should not have a license to practice law.

Courts make decisions all the time that are justified by the truth or falsity of a substantive moral position. That's the point of Charles Lawrence's reading of Brown v. Board of Education. ${ }^{106}$ What was wrong with segregation? It communicated a false message of inferiority to AfricanAmerican schoolchildren, and because it expressed this false and stigmatizing idea, it was inconsistent with the constitutional value of equality found in the Fourteenth Amendment. This isn't an empirical argument that can be resolved by looking at "neutral" facts-it's a political and moral position about the constitutional value of racial equality and, I might add, the relative importance of First Amendment freedoms like the right to associate with whomever one pleases. I might also add that Lawrence's argument is not some idiosyncratic critical race perspective.

106. Lawrence, supra note 12 , at 438-39. 
Mainstream legal scholars are infatuated with the idea that legal rules should be judged according to the moral values they express, ${ }^{107}$ and Lawrence's expressivist reading of Brown is often echoed by theorists with very different ideological backgrounds. ${ }^{108}$

CL: These "expressive" theories are just policy arguments-they have no basis whatsoever in existing law.

NL: I'll try another angle. (I want you to see that this argument of Lawrence's is actually quite mainstream, jurisprudentially speaking.) Consider Ronald Dworkin, who is the canonical liberal political philosopher. I think Dworkin is saying exactly the same thing as Lawrence concerning constitutional values. Although you probably don't like to admit it, your favorite liberal theorist's position provides a basis for excluding Hale from the Illinois bar. ${ }^{109}$

Dworkin says that a legal decision-a statute, a judicial decision, or an administrative action-must express the community's substantive moral and political principles in order to be legitimate. ${ }^{110}$ We care about a state that is just and about law that is fair. Of course, people disagree about what principles are just and fair, but state actors cannot refuse to decide while they ponder the right thing to do. They must act, and when they do, they must act as if they are expressing a single, coherent set of principles.

107. See, e.g., Elizabeth S. Anderson \& Richard H. Pildes, Expressive Theories of Law: A General Restatement, 148 U. PA. L. REV. 1503 (2000); Dan M. Kahan, What Do Alternative Sanctions Mean?, 63 U. CHI. L. REV. 591 (1996); Richard H. Pildes \& Elizabeth S. Anderson, Slinging Arrows at Democracy: Social Choice Theory, Value Pluralism, and Democratic Politics, 90 ColuM. L. REV. 2121 (1990); Richard H. Pildes \& Richard G. Niemi, Expressive Harms, "Bizarre Districts," and Voting Rights: Evaluating Election-District Appearances After Shaw v. Reno, 92 MicH. L. REV. 483 (1993); Cass R. Sunstein, On the Expressive Function of Law, 144 U. PA. L. REV. 2021 (1996).

108. See, e.g., OWEn M. Fiss, The Irony OF FreE SPEECH 9 (1996); Akhil Reed Amar, The Case of the Missing Amendments: R.A.V. v. City of St. Paul, 106 HARV. L. REV. 124 (1992); Charles L. Black, Jr., The Lawfulness of the Segregation Decisions, 69 YALE L.J. 421 (1960); Paul Brest, The Supreme Court, 1975 Term-Foreword: In Defense of the Antidiscrimination Principle, 90 HARV. L. REV. 1 (1976); Kenneth L. Karst, The Supreme Court, 1976 Term-Foreword: Equal Citizenship Under the Fourteenth Amendment, 91 HARV. L. REV. 1 (1977); Cass R. Sunstein, The Anticaste Principle, 92 MiCH. L. REV. 2410 (1994).

109. At this point, I am fairly certain that my hypothetical new left critic diverges from any actual progressive or critical theorist writing about the First Amendment. Dworkin is something of a bête noire in those circles, although it is not always easy to see why. His argument that legal systems ought to be understood as expressing a coherent conception of the community's values is obviously at odds with the strand of CLS theory that emphasizes the incoherence of legal doctrine, but fits more nicely with some critical race scholars who emphasize the existence of an anticaste principle in the Fourteenth Amendment, or who understand rights as providing a space for outsiders to exist within the dominant culture and address the powerful in terms they themselves favor. To avoid misunderstanding, the Dworkin-based passages should be taken as my own idiosyncratic approach to the critique of civil libertarianism, not the reconstruction of other scholars' arguments.

110. RONALD DWORKIN, LAW's EMPIRE 164-68 (1996) [hereinafter DWORKIN, LE]. 
CL: Why on earth do you impose that requirement? The law does not have to be perfectly coherent. Look at the First Amendment! It looks more like a Rube Goldberg device than a well-designed machine.

NL: Do you really want to abandon the ideal of coherence in law? Sure, the First Amendment is a mess, but civil libertarians are forever coming up with theories to explain how all the pieces fit together. You also get awfully exercised if a decision doesn't cohere with the existing cases. Listen to the arguments you have been making about Hale. It disturbs you that the Illinois bar committee's decision does not fit with the principle that insulting speech should be protected, or that restrictions on speech must be viewpoint-neutral.

CL: Of course generality and consistency are what the rule of law is all about. Judges must treat like cases alike. That is what prevents the state from arbitrarily granting favors to some and punishments to others on the basis of rules that do not apply generally.

NL: What would be wrong with granting benefits differentially if there was a reason to do so? In other words, if we could make the world a better place by denying Hale's law license, but granting a law license to Thurgood Marshall, shouldn't we do just that?

CL: Absolutely not! That would violate Hale's right to expressive freedom, which is an aspect of the rule of law.

NL: Okay, this is Dworkin's point. The right you defend cannot be justified solely on the basis of its tendency to do good, because we have stipulated that we could do more good by denying it in this case. A pragmatic defense of the rule of law, which points to the good consequences that flow from channeling the state's coercive force in a particular way, cannot support a nonstrategic account of rights. ${ }^{111}$ True, judges might want to act as though people had rights because this "noble lie" would promote stability and predictability and have good consequences in the long run. Taking rights seriously means adhering to them even when violating them would lead to a better future. ${ }^{112}$ You obviously do take rights seriously-you want to give Matthew Hale a "trump card" over the state's vision of a better society in which racial equality is respected. In order to make that kind of argument, you need to ground Hale's right in some virtue of the legal system.

You remember that rights are one of the central points of contention between two groups of new left critics-the critical legal studies "CLS" movement and the critical race theory movement. Where some CLS scholars tend to emphasize the indeterminacy of rights and the manipu-

111. Id. at $151-64$.

112. Id. at 160 . 
lability of rights discourse ${ }^{113}$ critical race theorists have described how rights are a very important means for marginalized groups to address their concerns to the majority. ${ }^{114}$ Rights enable outsiders to describe their experience in the normative language that the dominant group understands, appealing to values like stability and fairness that are an accepted part of the majority's moral scheme. Rights force the in-group to live up to their own ideals by showing that it is impossible, consistent with one's other values, to treat members of the out-group unfairly.

In other words, if we could do some good in the world by treating like cases differently, by treating rights purely strategically, yet we think we have reason not to do so, there must be some deep metatheoretical reason for insisting that a scheme of legal rules be coherent, or possess the virtue of integrity, as Dworkin calls it. ${ }^{115}$ That reason is legitimacy: Citizens have an obligation to obey the law (as opposed to a prudential reason to obey, lest they suffer punishment) only if there is a good moral reason to treat the commands of law as reasons for them to act or refrain from acting. ${ }^{116}$ All that future good consequences can give us are strategic reasons for respecting rights. Integrity, by contrast, calls upon judges to give an account of rights that is ultimately grounded in each member of the political community's obligations of respect and concern for other community members. ${ }^{117}$ When we treat each other as equals, we express that respect by making certain sacrifices for one another. Thus, even though we disagree about what justice and fairness require, we accept legal rules as legitimate if they are based on a coherent conception of the community's moral values which tries to make the best sense of all the conflicting, contradictory positions of individual members.

CL: Why do you need to harmonize all of these conflicting beliefs into one coherent position? Why not just let the disagreement play out in the political sphere? People can vote for legislators and executive-branch leaders at the state and federal level, and those officials will enact legislation and regulations that have as their basis a substantive moral position.

NL: What reason would someone have to respect those legal rules?

CL: The same reason one would have to respect any other bargain. We accept negotiated compromises reached between competing interests as legitimate because they keep the peace. They permit us to go about our lives knowing when the state will intervene in our affairs. That's all the claim to respect the law needs.

113. Mark Tushnet, An Essay on Rights, 62 TEX. L. REV. 1363 (1984).

114. Patricia J. Williams, Alchemical Notes: Reconstructing Ideals from Deconstructed Rights, 22 HARV. C.R.-C.L. L. REV. 401 (1987).

115. DWORKIN, LE, passim.

116. Id. at 190-215.

117. Id. at $199-202$. 
NL: I disagree. I think the law needs to be grounded in a "scheme of principles" that is presupposed by any legal rule, whether a piece of legislation or a judicial decision. ${ }^{118}$ What the law seeks to do is to fit rules into a public narrative_"an overall story worth telling now"119-that gives meaning to the community's political practices. You know the famous analogy of a chain novel. ${ }^{120}$ Each legal actor writes a new chapter, trying to make the novel the best it can be, but constrained by the necessity of fitting the new chapter with the ones written previously. Criteria of what makes a good interpretation are supplied by the ideal of integrity and the attempt to show the community's structure of institutions and rules in the best possible light from the standpoint of political morality. ${ }^{121}$ And in the case of our society, we have to recognize the increasing importance of the value of equality, which is "one of the center beams of the legal order," as Owen Fiss notes. ${ }^{122}$

CL: What if there is no common "scheme of principles"? I am a civil libertarian because, if there's one thing that is clear to me, it is that we live in a pluralistic society in which people disagree about practically everything-certainly every political issue of consequence. I cannot imagine how you would discover a coherent scheme of principles that is accepted by everyone in this society and which could serve as the moral basis for legal decisions. I suppose that makes me, as the English political philosopher John Gray terms it, an agonistic liberal. ${ }^{123}$ I believe in the centrality and irresolvability of conflict over rights, the good, and political theory itself, so the last thing I want is for government to take a position on any of these issues.

NL: But don't you see, judges have to make decisions on the basis of something, even when there are competing principles at work in the law. Dworkin gives an example of a tort case in which two principles apply: First, that the costs of accidents should not fall solely on the injured party, and, second, that a loss should not be borne by a party not at fault for the accident. ${ }^{124}$ Both of those principles clearly exist in the legal system, and they conflict in Dworkin's hypothetical. Do you propose that the judge just flip a coin? Unless you believe that a decision in a case like this is grounded in nothing more substantial than chance, or what the judge had for breakfast, you must grant that the result is justified by some

\footnotetext{
118. Id. at $211,243$.

119. Id. at 227 .

120. Id. at 228-38.

121. Id. at 255-56.

122. FISS, supra note 108, at 11.

123. JOHN GRAY, ISAIAH BERLIN (1996).

124. DWORKIN, LE, supra note 110 , at 1 and passim.
} 
principle of political morality. ${ }^{125}$ What you decry as "just policy arguments" are the moral basis for the legitimacy of law.

CL: This is what troubles me. Whose morality are we talking about? The judge's? Why does she get to decide that moral issue? Rights and principles are contested, so I don't understand why you remove them from the democratic process and permit judges to make decisions based on their own moral values. ${ }^{126}$

NL: No, those moral principles are found within existing judicial decisions. Back to Brown: You have a Supreme Court case saying that a government action that has the effect of stigmatizing individuals based on their race is wrong. ${ }^{127}$ That moral principle is now a part of our legal system, and any future legal judgment must take it into account. There are other cases, like Wisconsin $v$. Mitchell, ${ }^{128}$ which recognize the unique injury caused by hate crimes. Since Matthew Hale refuses to accept the value of racial equality, admitting him to the bar would not fit with the paramount moral value established by Brown and all the other cases canvassed by Charles Lawrence. Similarly, since he is stirring up hate and encouraging his followers to commit crimes, the best way to fit this case with the principle underlying Mitchell is to deny his application.

CL: I don't see how you can possibly shoehorn all the cases and statutes that define Dworkinian values into one coherent "scheme of principles." You talk about Brown and the value of racial equality, but what about a case like Buckley v. Valeo, ${ }^{129}$ which holds that speech may not be limited, even to correct for inequalities in political power? The Court has also consistently held that state actors may not impose content-based restrictions on speech to protect the constitutional value enshrined in the Establishment Clause. ${ }^{130}$ Similarly, the Court's affirmative action cases stand for a conception of equality, namely strict color-blindness, which is different from the kind of historicized conception of substantive equality that you favor. ${ }^{131}$ It seems to me that for every principle you point to, a reasonably alert lawyer could find a counter-principle. I don't see any coherence at all, let alone a coherent narrative that prioritizes racial equality over expressive freedom.

125. RonAld DWORKIN, A MATTER OF PRINCIPLE 74-79 (1985).

126. See Jeremy Waldron, Law ANd Disagreement (1999); Robert H. Bork, Neutral Principles and Some First Amendment Problems, 47 IND. L.J. 1 (1971).

127. Brown v. Board of Educ., 347 U.S. 483, 495 (1954).

128. 508 U.S. 476 (1993).

129. 424 U.S. 1 (1976).

130. Good News Club v. Milford Cent. Sch., 533 U.S. 98 (2001); Lamb's Chapel v. Center Moriches Union Free Sch. Dist., 508 U.S. 384 (1993).

131. Adarand v. Peña, 515 U.S. 200 (1995); Richmond v. J.A. Croson Co., 488 U.S. 469 (1989). 
VI

\section{WHO IS THE SKEPTIC?}

CL [cont'd]: I'll grant you that, by our lights, Hale's beliefs are morally wrong and harmful. But if you permit the denial of Hale's law license because he's a racist, then what follows? What if a different government were in power-say, George Wallace in Alabama in the early 1960s? Then a lawyer who wanted to challenge the regime of Jim Crow would be denied admission to the bar because he showed disrespect for the law. The idea of lawyer exceptionalism - the notion that lawyer have diminished expressive liberties because of their relationship with the rule of law-is even more frightening when you consider that the rule of law has not always been protective of the groups you want to protect.

NL: Here's that move again! You sneak in these relativist premises- "by our lights" or "what if a different government were in power?"-as if truth were a function of political majorities. But Dworkin's point is that these values can be discerned in the legal system itself; they are not subjective beliefs of individual judges. He couldn't be clearer about this:

Judges may not read their own convictions into the Constitution. They may not
read the abstract moral clauses as expressing any particular moral judgment, no
matter how much that judgment appeals to them, unless they find it consistent in
principle with the structural design of the Constitution as a whole, and also with
the dominant lines of past constitutional interpretation by other judges. They
must regard themselves as partners with other officials, past and future, who to-
gether elaborate a coherent constitutional morality, and they must take care to
see that what they contribute fits with the rest.

The Court in Brown had no trouble concluding that the governments of every Southern state were simply wrong about segregation in schools. The equal protection clause forbids stigmatizing African-American students by forcing them to attend separate schools. The formal racial equality of separate but equal schools was not enough to satisfy the Fourteenth Amendment. The only way to give effect to the Equal Protection Clause in public education was to demand a different kind of equalitythe absence of the stigma of state-sponsored apartheid. ${ }^{133}$

That is a long answer to your question of why it would have been wrong to deny admission to a black lawyer in 1960, but it's not wrong to deny admission to Hale today.

CL: What's the difference?

NL: We're right, they're wrong.

CL: But wouldn't George Wallace say the same thing?

132. Ronald Dworkin, Freedom's LAw: THE MORAL REAding OF THE AMERICAN CONSTITUTION 10 (1996) [hereinafter DWORKIN, FL].

133. Brown v. Board of Educ., 347 U.S. 483, 495 (1954). 
NL: He'd be wrong, we'd be right.

CL: This isn't getting anywhere.

NL: No, actually we're on to something here. One of us believes in truth, objectivity, and the relevance of moral values to legal decisionmaking; the other does not.

CL: Now I've heard everything! A postmodern, multicultural theorist talking about values and objectivity. I thought you believed in the social construction of truth, the contingency of value, the relativity of ethics, the absence of foundations, and all of that. ${ }^{134}$

NL: That's a misreading of the progressive position. First Amendment theorists like Mari Matsuda have been perfectly clear that they are calling for a "non-neutral, value-laden approach" 135 to deciding First Amendment cases. It's just that they're honest about the relevance of values to the legal decision. All we are asking is for both sides to lay their cards on the table.

The alternative is to create unwarranted doctrinal complexity. Think of the hate-speech case that everyone reads in torts class, Fisher v. Carrousel Motor Hotel. ${ }^{136}$ The court ties itself in knots making an incident of racial discrimination into a battery, just because the hotel manager snatched a plate out of the hand of an African-American customer. I have lots of fun with that case in my torts class, asking my students how much contact is enough to constitute a battery, but eventually someone figures out that it's not a battery case at all. Richard Delgado is right that, in a few cases, the tort system recognizes racial insults as actionable injuries, and that we ought to strip away the mystification and directly recognize the cause of action. ${ }^{137}$

Ironically, it's actually you civil libertarians who are committed to a position that denies the possibility of moral objectivity. You cannot abide any government decision that is based on substantive moral valuesthat's what all the emphasis on content- and viewpoint-neutrality is all about.

CL: That's right, because substantive moral values are contestable. People disagree, and even when they don't disagree, we can never be sure that we know the truth. As Mill said, "[w]e can never be sure that the opinion we are endeavoring to stifle is a false opinion." 138 For that reason, we

134. E.g., Daniel A. Farber \& Suzanna Sherry, Beyond All Reason: The Radical ASSAUlt ON TRUTH IN AMERICAN LAW 23-40, 95-112, 121 (1997); Goodpaster, supra note 23, at 659.

135. Matsuda, supra note 11, at 2357.

136. 424 S.W.2d 627 (Tex. 1967).

137. Richard Delgado, Words That Wound: A Tort Action for Racial Insults, Epithets, and NameCalling, 17 HARV. C.R.-C.L. L. REV. 133 (1982) [hereinafter Delgado, Words].

138. J.S. Mill, On Liberty, in ON LiBerTy AND OTHER WRITINGS 1, 20 (Stefan Collini ed., Cambridge University Press 1989). 
don't want the government making moral decisions for people. That's what the Court meant when it said in Gertz v. Robert Welch, Inc., ${ }^{139}$ that "there is no such thing as a false idea." "140

NL: But don't you see? That's a moral position you're asserting!

CL: No, it is neutrality among moral positions. It is an attitude of toleration that does not endorse any of the competing systems of substantive values that people bring to public debate-their "comprehensive views," as John Rawls calls them. ${ }^{141}$ The First Amendment guarantees government neutrality among ideas competing for acceptance in the metaphorical marketplace. How is the civil libertarian position of neutrality not neutral?

NL: It's an ideology about how people ought to interact with one another, what kind of institutions they should set up, what kinds of speech and conduct are acceptable and what is out of bounds. The principle of content-neutrality actually draws lines-it just pretends not to. ${ }^{142}$ Or, to put the point another way, you claim that the First Amendment is somehow "above" politics, but you have not noticed how politics has been smuggled inside your position. Stanley Fish has been making this point for years: "[S]ince speech is unimaginable apart from consequences and since the consequences of any piece of speech will be friendly to some interests and inimical to some others, the decision to draw a line between protected and regulated speech will always be a decision to advance some interests and discourage others, will always, that is, be a political decision." ${ }^{143}$ To get back to the Hale case, you have made a political decision to deny admission to applicants who engage in a particular kind of speech-act-lying about speeding tickets—while admitting applicants who engage in another kind-advocating violence against people of color and Jews. Fish is simply asking you for a political justification for that distinction, instead of the spurious argument from neutrality.

CL: You seem to think that I am engaging in some kind of covert moral argumentation, but the civil libertarian argument aims to take those decisions out of government hands and put them where they belong-in the hands of individuals.

NL: I'll give you an example of the normative underpinnings of the legal rules you take for granted: We regulate obscenity because we think it protects children and because our community is well served by marking off a

139. 418 U.S. 323 (1973).

140. Id. at 339-40.

141. JOHN RAWLS, POLITICAL LiBERALISM 12-13 (1993).

142. STANLEY FISH, There's No Such Thing as Free Speech, and It's a Good Thing, Too, in THERE'S No Such Thing As Free Speech, AND IT's a Good Thing, Too 102 (1994). See also Steven H. SHIFFRIN, THE FIRST AMENDMENT, DEMOCRACY, AND ROMANCE 88-90 (1990).

143. Stanley Fish, The Trouble With Principle 94 (1999). 
boundary between the decent and the loathsome. That's what the government is doing, and it gets a value of $X$, however we want to measure value. On the other hand, producers of obscene speech have interests in self-expression, in shocking people, in making money, and so on. Those interests get a value of $Y$. Quite simply, the Court has determined that $X$ $>Y$. It could have come out the other way. In the flag-burning cases, where $X$ is honoring the central symbol of the country, protecting patriotic Americans from emotional harm, and maintaining a sense of public order in chaotic, changing times, and where $Y$ is the value of permitting political dissent to flourish and permitting the self-realization of flagburners, the Court has decided that $X<Y$. The Court is doing simple back-of-the-envelope cost-benefit analysis. It is not an apolitical exercise.

This is an old point—almost a cliché in First Amendment scholarshipbut courts are permitted to discriminate on the basis of content. Think of all of the categories of speech which are given a lesser degree of protection or no protection at all: obscenity ${ }^{144}$ defamation; group libel ${ }^{145}$ fighting words ${ }^{146}$ commercial speech; certain kinds of expressive conduct, like nude dancing ${ }^{147}$ and draft-card burning, ${ }^{148}$ that makes political elites uncomfortable; conduct that occurs through the medium of speech, for instance criminal solicitation and discrimination; speech to a captive audience; ${ }^{149}$ speech that is likely to be overheard by children; ${ }^{150}$ and so on. Fish's point is that speech never has value in and of itself. These categories aren't natural types, and they're not value-neutral. Rather, we draw lines around protected speech because we want to do something elsefind the truth, safeguard political dissent, facilitate democratic decisionmaking, whatever. ${ }^{151}$ We recognize that speech is aimed at doing something and suppressing speech is aimed at doing something. The normative question then concerns the relative importance of what the speech is doing versus what the government is up to when it regulates speech.

All of the existing categories of unprotected speech are set up the way they are because of value judgments we have made. And if you argue that nude dancing is unprotected but that Nazi demonstrations are pro-

144. See Renton v. Playtime Theatres, 475 U.S. 41 (1986); Young v. Am. Mini Theatres, 427 U.S. 50 (1976).

145. See Beauharnais v. Illinois, 343 U.S. 250, 276 (1952).

146. See Chaplinsky v. New Hampshire, 315 U.S. 568, 572 (1942).

147. See Barnes v. Glen Theatre, Inc., 501 U.S. 560, 571 (1991).

148. See United States v. O'Brien, 391 U.S. 367, 376 (1968).

149. See Erznoznick v. City of Jacksonville, 422 U.S. 205, 210 (1975).

150. See FCC v. Pacifica Found., 438 U.S. 726, 750 (1978).

151. FISH, supra note 142, at 104. 
tected, I have to conclude that the value you are concerned with is protecting Nazis. ${ }^{152}$

CL: Wait! Before you go on, I just wanted to point out that critics in your camp, like Delgado, Matsuda, Lawrence, and Fish, always point to the same categories and the same old, mostly discredited cases. Chaplinsky is a dead letter-look at all the cases refusing to apply it to serious provocations. ${ }^{153}$ Everyone thinks Beauharnais is defunct after New York Times v. Sullivan. ${ }^{154}$ The case about burning draft cards is anomalous, probably wrongly decided on its own terms, and certainly called into question by the flag-burning cases. ${ }^{155}$ And don't forget about $R . A$.V., which is a case about racist hate speech, or at least expressive conduct, in which the Court said that the regulation in question was invalid as a content-based restriction on expression. ${ }^{156}$

You were saying ...

NL: Whatever the current state of the categories of favored and disfavored expression, if there are categories at all, then there is no politics-free perspective from which they can be constructed..$^{157}$ That's not an objection to the practice of drawing lines and protecting some utterances and leaving others unprotected. But let's at least be honest about the political value judgments we are making.

Randall Kennedy has given a good example of this covert evaluative process at work. ${ }^{158}$ Suppose there are two private universities in your state: Clean Speech U. and Free Speech U. At Clean Speech U., the emphasis is on civility in dealing with one another-no profane language, no insults or epithets, and everyone must be addressed by their last names, Mr. and Ms. So-and-so. Free Speech U. has none of these rules. People can insult one another freely, swear all they like, publish scurrilous articles about professors in the campus newspaper-you get the picture. (Paul Converse would love it there; he would probably sell out of "Deanie on a Weenie" T-shirts.) Now suppose the state government wishes to reform

152. See Delgado \& STEFANCIC, supra note 98.

153. See, e.g., Texas v. Johnson, 491 U.S. 397, 409 (1989); Lewis v. New Orleans, 415 U.S. 130, 132 (1974); Hess v. Indiana, 414 U.S. 105, 107 (1973); Gooding v. Wilson, 405 U.S. 518, 528 (1972); Brandenburg v. Ohio, 395 U.S. 444, 448 (1969).

154. 376 U.S. 254 (1964).

155. United States v. Eichman, 496 U.S. 310 (1990); Texas v. Johnson, 491 U.S. 397 (1989).

156. R.A.V. v. City of St. Paul, 505 U.S. 377 (1992). Once again, the Court was loose with its terminology. The city ordinance at issue was actually a viewpoint-based restriction on speech; the Court noted that a sign urging racial tolerance would not be prohibited by the ordinance, while cross-burning would be. $I d$. at 391-92. A content-based regulation would prohibit all speech pertaining to race, regardless of whether the message conveyed was positive or negative. Thanks to my colleague Ron Krotoszynski for pressing me to clarify this distinction.

157. FISH, supra note 142, at 113.

158. Randall Kennedy, Hate Crimes/Hate Speech, in SPEeCH AND Equality: Do We Really HAVE To CHOOSE? 70, 71 (Gara LaMarche ed., 1996). 
education, and one of the items on its agenda is the kind of speech that should be allowed at universities. Is there any way to decide, based on "neutral" principles, whether the educational environment offered by Free Speech U. is superior to Clean Speech U., or vice-versa? I don't think so. You can only decide which of these models to favor by engaging in a substantive argument about the nature of a good academic community. That's okay, of course, but you can't pretend that it's a valueneutral exercise.

Martin Redish thinks it's an effective response to this hypothetical to say that Kennedy would have a hard time dealing with something like $\mathrm{Ku}$ Klux Klan U., where a bunch of white supremacists band together and exclude those who disagree with them. ${ }^{159}$ But it's Redish who cannot justify banning $\mathrm{Ku}$ Klux Klan U. but yet keeping Free Speech U. open solely on the basis of neutral principles. He has to argue that segregation is substantively wrong-morally, constitutionally, politically, practically, whatever-while wide-open expressive freedoms, including the right to engage in bigotry, is acceptable. Why not just bite the bullet and admit that you are making a normative argument? It's because you would then have to admit that there is no good reason for letting Matthew Hale become a lawyer.

Here's another way the civil libertarian position is not neutral: You talk about the right to free speech as if everyone had the same ability to speak. But they do not. For one thing, permitting hate speech to flourish has the effect of silencing its victims. ${ }^{160}$ It does not contribute to the discovery of truth in the marketplace of ideas because the people to whom it is directed are essentially beaten into submission. Look at the stories told by those who have been subjected to this kind of verbal assault. They find themselves "in a state of semi-shock, nauseous, dizzy, unable to muster [a] witty, sarcastic, articulate rejoinder"; ${ }^{161}$ feeling like they have been hit in the gut, with symptoms of severe emotional distress, such as "rapid pulse rate and difficulty in breathing, nightmares, post-traumatic stress disorder, hypertension, psychosis, and suicide."162 Members of the target group are well aware of how these encounters can escalate into violence-names like Vincent Chin, Matthew Shepherd, and James Byrd, and the memories of victims whose names have not become national buzzwords, like the African-American couple shot to death in North

159. Discussion, Hate Crimes/Hate Speech, in SpeECH And Equality: Do We Really Have to CHOOSE? 72, 80 (Gara LaMarche ed., 1996).

160. FISS, supra note 108, at 5-26; Richard Delgado \& David Yun, The Neoconservative Case Against Hate-Speech Regulation-Lively, D'Souza, Gates, Carter, and the Toughlove Crowd, 47 VAND. L. REV. 1807, 1822-24 (1994); Frank Michelman, Conceptions of Democracy in American Constitutional Argument: The Case of Pornography Regulation, 56 TENN. L. REV. 291, 303-04 (1989).

161. Lawrence, supra note 12, at 455.

162. Matsuda, supra note 11, at 2332, 2336. 
Carolina as an initiation ritual for a white supremacist group, ${ }^{163}$ or the Vietnamese-American high school student who was stabbed to death after enduring months of racial insults, ${ }^{164}$ are never far from their minds. ${ }^{165}$

Once again, there are mainstream jurisprudential analogues with my argument. The best example is John Ely's reading of footnote four in the Carolene Products opinion. ${ }^{166}$ According to Ely, the Bill of Rights should be interpreted to provide special protection to "discrete and insular minorities," those groups to whom the democratic process cannot be expected to be responsive. Judicial review of majoritarian decisions is justified as an attempt to correct for "market failure" in the political process. That's all that proponents of hate speech regulation are proposing-they just want to ensure that everyone's voice is heard, and not driven from the marketplace of ideas through intimidation.

\section{The Public/Private Distinction}

CL: The natural response to that argument is that the inequality effects you describe are the result of private, not state, action. ${ }^{167}$ There is no equal protection violation when an individual utters a racist slur or expresses an opinion about the inferior status of women. In certain circumstances there may be a statutory cause of action against the speaker-if the speech occurs in the workplace, for example-but there is still no violation of the Fourteenth Amendment. Thus, you don't have another constitutional right to trade off against the First Amendment, which still trumps the asserted equality right.

NL: The problem with a formalist doctrine, like the public/private distinction, is that it is blind to the reality of diffuse racism. The system of white supremacy is not limited to discrete, observable state actions. ${ }^{168}$ Rather, it is the synergistic effect of private acts and state indifference. Look at

163. Walter M. Hudson, Racial Extremism in the Army, 159 MIL. L. REV. 1 (1999).

164. Matsuda, supra note 11, at 2332, 2335.

165. See also Robin D. Barnes, Blue by Day and White by (K)night: Regulating the Political Affiliations of Law Enforcement and Military Personnel, 81 IOWA L. REV. 1079 (1996) (recounting numerous incidents of hate crimes committed by members of white supremacist organizations).

166. JOHN HART ELY, DEMOCRACY AND DISTRUST (1980).

167. James Weinstein, Hate SPEech, Pornography, and the Radical AtTack on Free SPEECH DOCTRINE 85-90 (1999); Martin Redish, Hate Crimes/Hate Speech, in SPEECH AND EQuality: Do We Really Have to Choose? 64 (Gara LaMarche ed., 1996); Susan Gellman, Hate Speech and $a$ New View of the First Amendment, 24 CAP. U. L. REV. 309, 311-12 (1995).

168. Lawrence, supra note 12, at 443-49; Richard Delgado, Campus Antiracism Rules: Constitutional Narratives in Collision, 85 Nw. U. L. REV. 343, 383-86 (1991); Charles Lawrence, The Id, the Ego, and Equal Protection: Reckoning with Unconscious Racism, 39 STAN. L. REV. 317 (1987). For general jurisprudential discussion of the public/private distinction, which is a favorite subject for critical legal scholars, see, e.g., FISS, supra note 108, at 17-18; Morton J. Horwitz, The History of the Public/Private Distinction, 130 U. PA. L. REV. 1423 (1982); Duncan Kennedy, The Stages of the Decline of the Public/Private Distinction, 130 U. PA. L. REV. 1349 (1982). 
Brown again. It wasn't just segregated schools that were the problem. It was the way "separate but equal" schools would be perceived by a racist society and how segregation would reinforce the existing attitudes of inferiority perpetrated by the Jim Crow regime. ${ }^{169}$ Even today the socially constructed ideology of racism is the status quo, so we cannot see how legal rules that leave existing structures of private power in place actually perpetrate racism. ${ }^{170}$ Hate speech props up that ideology by distancing people of different races and perhaps subconsciously operating to convince them of the truth of racist stereotypes. ${ }^{171}$

Once again, your position purports to be neutral but it is not. As Charles Lawrence puts it, the state action doctrine to which you appeal embodies a value judgment - the judgment that the equality and dignity interests of people of color ought to be outweighed by the interest that racist speakers have in freedom of expression. ${ }^{172}$ Civil libertarians could argue for that evaluative conclusion (although I think they'd be wrong), but what drives me nuts is the attempt to circumvent the hard work of making the normative argument by pointing to the public/private distinction. We need to get beyond this kind of formalism in reading the Constitution and take a more realist approach to combating racism. ${ }^{173}$

CL: If I were laying money I'd wager that this argument is so radical that it is unlikely ever to garner the support of courts. ${ }^{174}$ The public/private or state action doctrine is pretty well entrenched. I concede that it is not wertfrei, as the sociologists say, but I think you misunderstand the nature of arguments based on it. Civil libertarians are well aware that private actors, or even society generally, can inflict stigmatizing or humiliating injuries, but they are more worried about what will happen as the result of giving the government too much power to regulate the content of individuals' thoughts and speech.

Anyway, your argument proves too much. ${ }^{175}$ Plenty of speech has the effect of silencing other participants in the marketplace of ideas, but I don't think you would be willing to regulate it. For example, suppose you had an acquaintance who was an out-and-out bigot. If every time he expressed his bigotry he was mocked by his peers, eventually he'd figure out that he ought to keep his mouth shut about his opinions. That is, he would be silenced. I take it, though, that you would regard this as "good

169. Brown v. Bd. of Educ., 347 U.S. 483, 495 (1954).

170. Charles R. Lawrence III, The Id, the Ego, and Equal Protection: Reckoning with Unconscious Racism, 39 Stan. L. Rev. 317 (1987).

171. Matsuda, supra note 11, at 2339-40; Delgado, Words, supra note 137, at 136-38, 145-46.

172. Lawrence, supra note 12 , at 446-47.

173. J.M. Balkin, Some Realism About Pluralism: Legal Realist Approaches to the First Amendment, 1990 DUKE L.J. 375.

174. See, e.g., Goodpaster, supra note 23, at 660-61.

175. See DWORKIN, FL, supra note 132, at 232. 
silencing," not the "bad silencing" you fear as a result of racist hate speech. This distinction brings us right back to the problem I continue to have with your proposals - they involve powerful officials in determinations of good and bad opinions, beliefs, ideas, silencing, and so on.

\section{VIII}

\section{THE GOVERNMENT: FRIEND OR FOE?}

CL [cont'd]: These observations can be summarized in a pragmatic response to your position. As soon as the government gets into the business of drawing lines between favored and disfavored speakers, you have to worry about abuses of that power. ${ }^{176}$ The new left critics seem to assume that restrictions on speech will always be applied to silence the Nazis and the Klan, while radical and inflammatory speakers on the left, like Leonard Jeffries and Louis Farrakhan, will be permitted walk the fine line between protest and "assaultive" or racist speech without getting in trouble. ${ }^{177}$ It doesn't always work that way, though. Do you remember Rudy Giuliani's battle with Khalid Muhammad over permits for the Million Youth March in New York? (Come to think of it, Rudy Giuliani's efforts to silence anyone who disagreed with him!) Look at countries which have adopted hate speech regulations and notice what happened. After the Canadian government passed an anti-pornography statute along the lines suggested by Andrea Dworkin and Catharine MacKinnon, the authorities used it to prosecute the owner of a gay and lesbian bookstore and to confiscate copies of a book by bell hooks as a possible incitement of hatred. ${ }^{178}$ The only successful prosecutions under the British hate speech statute have been of black people allegedly stirring up hatred against white people. ${ }^{179}$ As for college hate speech regulations, that record is also not so encouraging. In the first year after the University of

176. Ira Glasser, Hate Crimes/Hate Speech, in SPEECH AND Equality: Do We ReAlly HaVE TO Choose? 55 (Gara LaMarche ed., 1996); Henry Louis Gates, Jr., Let Them Talk: Why Civil Liberties Pose No Threat to Civil Rights, NEw RePublic, Sept. 20, 1993, at 37; Goodpaster, supra note 23, at 659.

177. Leonard Jeffries was fired as head of the Black Studies Department at CCNY for making what the college deemed to be racist remarks. On a federal civil rights challenge, his First Amendment claim was denied under the reasoning of Waters v. Churchill, 511 U.S. 661 (1994), that in effect the employer's interest in avoiding disruption in its workplace outweighed Jeffries's expressive liberties. Jeffries v. Harleston, 52 F.3d 9, 9 (2d Cir. 1995).

178. These incidents are a staple of civil libertarian responses to calls to restrict hate speech, particularly since new left critics like Mari Matsuda have used the Canadian example as evidence that a free society can tolerate some restrictions on racist expression. E.g., Ronald J. Krotoszynski, Jr., Dissent, Free Speech, and Continuing Search for the "Central Meaning" of the First Amendment, 98 MiCH. L. REV. 1613, 1631 (2000). See also Gates, supra note 176, at 43; Gey, supra note 23, at $247 \mathrm{n} .154$. The constitutionality of the statute was decided in Regina v. Butler, [1992] 89 D.L.R. (4th) 449.

179. WeINSTEIN, supra note 167 , at 145. 
Michigan adopted such a restriction, twenty black students were charged by whites with violations of the hate speech code. ${ }^{180}$

You're assuming that government power will always be in the hands of people who are interested in protecting marginalized groups, or that the judges who administer these limitations on free expression will perceive the balance of harms the same way you do, but I just don't understand that confidence given the experience here and abroad. With the government in the hands of people like Tom DeLay, Trent Lott, and John Ashcroft, do you really want to give up the right to make value judgments for yourself?

This is where your argument becomes incoherent: By definition, marginalized groups don't have much popular support, and if there's anything political actors are responsive to, it's popular sentiment. Wasn't it Derrick Bell who said that black people will never achieve equality in this country? ${ }^{181}$ If he's right, then the last thing you want to do is hand over power to a government that does not respect racial equality. Indeed, the true test of the First Amendment is how well it will protect those who express unorthodox ideas at times when there is strong public sentiment in favor of their suppression. ${ }^{182}$ That is what civil libertarians mean when they say that free speech is necessary for the protection of racial equality, not antithetical to it.

NL: You civil libertarians are always harping on a couple of aberrational incidents in countries that have robust hate speech regulations, but you must know that these are isolated abuses, not at all typical of the way these statutes are generally administered. ${ }^{183}$

More substantively, I always find this argument odd, although I hear it constantly from civil libertarians. It is as though you cannot find a satisfying theory of the First Amendment that would justify protecting hateful expression, so you fall back on a strategic decision to hobble the power of the government in a particular way. ${ }^{184}$ The alleged principle you defendthe paramount value of free speech-is just a smokescreen! I have to thank you for making my argument for me. You couldn't have supplied a better demonstration of the correctness of the critical legal studies attack on the reification of legal rules and of the cynicism and intellectual dishonesty of legal liberalism. (And so much for your fulminations earlier

180. Gates, supra note 176 , at 45.

181. Derrick A. Bell, Jr., Racial Realism, in CRITICAL RACE THEORY 302, 306 (Kimberlé Crenshaw et al. eds., 1995).

182. Vincent Blasi, The Pathological Perspective and the First Amendment, 85 COLUM. L. REV. 449, 449-50 (1985).

183. Delgado \& STEFANCIC, supra note 98 , at 101, 125.

184. Bollinger, supra note 68 , at 626-27. 
about the new left position being just "policy," in contrast with your "legal" arguments!)

I would also note that you don't carry through this critique to all government action. Most of you ACLU types are New Deal Democrats. You support the welfare state, large-scale federal solutions to problems like poverty, pollution, and access to health care, and programs that give a lot of power to the government, at least where the government's power is limited to taxing and redistributing wealth. I find it interesting that civil libertarians are not generally libertarians simpliciter, the kind of people who rant about taxes being theft and who want to abolish the EPA and the Department of Education because they represent untoward concentrations of power in the government. If you really believe in taking power away from the state, why is your hero FDR and not Newt Gingrich?

If you like, though, I can perform the liberal dance of constructing post hoc rationales for legal judgments. The pragmatic argument assumes that there is no line that can be drawn between denying a law license to Matthew Hale and shutting down a gay and lesbian bookstore, or prosecuting Chris Rock for his repeated use of the n-word in standup routines? (This matters only if you take a non-strategic attitude toward rules, of course.) First of all, we're only talking about speech by a particular class of people whose speech is particularly powerful, namely lawyers. I am not proposing criminalizing racist speech generally, although some of my fellow travelers have made that suggestion. Second, the slippery slope arguments you civil libertarians are so fond of making are persuasive only if they reveal the impossibility of making a principled distinction between protected and unprotected speech. But there is a legitimate distinction available here: These sorts of decisions can be made on the basis of a rule that defines hate speech as something like speech that conveys a message of racial inferiority, that is directed toward a historically oppressed group, and that is hateful and degrading. ${ }^{185}$ In this case, the distinction would be clear. Hale's hateful activities convey a message of inferiority, unlike the Canadian bookstore which aims to bring a historically oppressed community together, to give it a voice, rather than to take away that voice, as Hale seeks to do. That's why I don't understand the civil libertarian argument that the constitutional values of racial equality and free expression are not in tension. Of course they are, if courts define with care the nature of the speech they are limiting in order to further equal-protection values. 
IX

\section{THE NORMATIVE BASIS FOR FIRST AMENDMENT LIBERTIES}

CL: I notice you are at least admitting that hateful speech conveys a message. Some of the new left critics try to argue that hate speech, or pornography, isn't the expression of an idea at all. They say it is more like a physical assault. ${ }^{186}$ You then have a hard time reconciling that argument with the other argument your friends make, which is that racist speech contributes to the social construction of racism in society. ${ }^{187}$ To me, that sounds like you fear racist speech because of the idea it conveys and its persuasive impact. Charles Lawrence talks about the idea of white supremacy becoming entrenched in society because of an aggregation of thousands of individual racist acts. ${ }^{188}$ In other words, he is worried about the cognitive impact of hate speech. That is certainly how Judge Easterbrook read the Indianapolis anti-pornography ordinance in Hudnut. ${ }^{189}$ He took it as self-evident that the harm to be avoided was the message of women's subordination conveyed by pornography. ${ }^{190}$

NL: I am not committed to the thesis that all hateful expression is harmful because it communicates an idea. Much of this garbage conveys only pure emotive harm. It really is more like a body blow than a debate. That is clearly Catharine MacKinnon's position, with respect to pornography. ${ }^{191}$ Pornography has effects, just like ideas have effects, but it operates differently than persuasive speech. Pornography is something that is done to women; it is analogous to discrimination, or rape. ${ }^{192}$ By the same token, a sign saying "whites only" is speech in the sense that it is symbolic communication of an idea, but the law conceptualizes it as conduct, as discrimination, rather than as expression..$^{193}$

All of the major new left theorists are simply working within the existing structure of constitutional categories. Mari Matsuda's objections run to the content of the idea proclaimed by racist speech and its falsity and harmfulness, which in some ways makes her proposal the most provocative. ${ }^{194}$ Charles Lawrence is more taken with the metaphor of fighting words, so his proposal is aimed at the assaultive nature of hate speech. ${ }^{195}$

186. See, e.g., Catherine A. MacKinnon, Pornography as Defamation and Discrimination, 71 B.U.L. REV. 793 (1991).

187. Henry Louis Gates, Jr., War of Words: Critical Race Theory and the First Amendment, in SPEAKING OF RACE, SPEAKING OF SEX 17 (Henry Louis Gates et al. eds., 1994).

188. Lawrence, supra note 12, at 443.

189. American Booksellers Ass'n v. Hudnut, 771 F.2d 323, 329 (7th Cir. 1985).

190. Id.

191. CATHARINE MACKINNON, ONLY WORDS 9-26 (1993).

192. Id. at 13 .

193. Id.

194. Matsuda, supra note 11, at 2358.

195. Lawrence, supra note 12 , at 451-57. 
Richard Delgado, too, conceives of hate speech as analogous to the invasion of personal security and mental tranquility that is made actionable in conventional tort law. ${ }^{196}$ That is a good distinction between many of the hate speech cases we are worried about and the free-speech precedents you cite, like the flag-burning case and the parody of the Campari ad attacking Jerry Falwell; those utterances were directed into the wider marketplace of ideas, while a great deal of racist speech is one-on-one, intended to intimidate, not to make a contribution (however crude) to public debate. ${ }^{197}$ As Robert Post points out, if Larry Flynt were to call up Jerry Falwell and ridicule his mother in the same terms he used in the Campari ad parody, the speech would not be constitutionally privileged. ${ }^{198}$ Speech matters, and should be protected, when it communicates an idea that is arguably worth paying attention to in a public forum.

In any event, two can play at this game of pointing out contradictions in opponents' arguments: The really bizarre thing about the civil libertarian position is that it's self-defeating. You stick up for people who have no commitment whatsoever to freedom of expression. If the Nazis came to power, they would not only clamp down on the speech of liberals who criticize the government, they would have them rounded up and shot. And, in the name of the free exchange of ideas, you support expression that isn't an attempt to exchange ideas at all-it's merely an effort at intimidation or harassment, more like a physical assault than a debate. People who were in Skokie in 1977 report the reaction of the Holocaust survivors to the Nazis: They were "almost in a catatonic state-petrified-shaking-crying." 199 That's not the result of a transaction in the marketplace of ideas. But because you have a formalistic view of the First Amendment, you can't see the difference between assaultive expression and speech that is aimed at furthering some kind of reasonable discourse.

CL: There are two different arguments going on here. The first one is pretty easy to refute. It is true that civil libertarians would protect speech by those who would deny it to others, but the alternative is to suppress speech, and that is precisely the harm to be avoided. It is precisely because the Nazis would deny the freedom of others to speak that we must protect it for the Nazis. Legal decisions, such as one to deny a law license to Matthew Hale, create precedents. If we permit restrictions on the expressive liberties of people we dislike, we risk undermining legal protections for speech that ought not to be suppressed. Remember, too, that

196. Delgado, Words, supra note 137, at 150-57.

197. Rodney A. Smolla, Rethinking First Amendment Assumptions About Racist and Sexist Speech, 47 WASH. \& LEE L. REV. 171, 184-85 (1990).

198. Robert Post, The Constitutional Concept of Public Discourse: Outrageous Opinion, Democratic Deliberation, and Hustler Magazine v. Falwell, 103 HARV. L. REV. 601, 662 (1990).

199. STRUM, supra note 68 , at 59. 
McCarthy sought to protect American democracy by clamping down on those he perceived as enemies, but all he succeeded in doing was making a mockery out of the democratic values he claimed to cherish.

The second argument is harder because it forces us civil libertarians to confront the costs of free speech. I don't know of any better answer than to say it's a matter of choosing the lesser of two evils, but I admit candidly that I don't know how to compare evils. It's horrible that the Holocaust survivors in Skokie have to see brown shirts and swastikas-I can see why they could barely control their rage. And I realize that the Skokie residents had considered what we civil libertarians are always telling people to do with racists-ignore them, deprive them of the attention they are seeking, and prevent racists and racist speech from being driven underground where it might be even more dangerous. ${ }^{200}$ I can't argue with a person who watched his two-year-old daughter die when a Nazi camp guard smashed her head with a rifle butt and now refuses to roll over and let the Nazis get away with demonstrating in his town ${ }^{201}$ or someone who lost her parents and her brother in the Warsaw Ghetto and is no longer willing to trust political elites to protect her from terror. ${ }^{202} \mathrm{I}$ believe that the United States is different from Weimar Germany and that Nazis could never attain power here, but I respect people who think otherwise, and for good reason.

I think that you, too, would be willing to require people to endure emotional harm from speech in some cases though. In these hypotheticals, I think you would probably favor protecting the speech. ${ }^{203}$ Case number one: A young draftee returns from Vietnam after being shot at, seeing his best friend blown up, and experiencing the terror and inhumanity of combat for a year. The moment he steps off the plane, he sees a poster saying "Support the Vietcong!" or a picture of Jane Fonda sitting in a North Vietnamese surface-to-air missile launcher. What kind of psychic impact do you think that would have? You talk about racist speech as making someone feel alienated from herself, but think of how this G.I. would feel after being turned into a killing machine by the government and then being told by his own fellow citizens that he is a loathsome person. Case number two: A woman has suffered through the trauma of rape and has agonized over whether to abort the fetus. When she finally manages to get up the courage to go to an abortion clinic, she is confronted with protesters screaming "baby killer!" and waving pictures of bloody fetuses. Isn't that political protest protected speech?

200. See id. at 18.

201. Id. at 20 .

202. Id. at 21.

203. These examples are from WEINSTEIN, supra note 167, at 162, although they and similar examples occur in much of the academic commentary critical of the new left position. 
I don't want to get into ranking harms here, and I wish in no way to trivialize the anguish that racist expression causes, but these political-protest cases seem indistinguishable from the hate speech you wish to regulate. The reason I can argue that the Nazis ought to be permitted to have their demonstration in Skokie, and the reason I have faith in the solidity of the American political order, is precisely because the system tolerates dissenting voices. That's a crucial difference between a system that would protect Jews from Nazis and one which would not.

NL: You say you don't want to get into ranking harms, but that is exactly what we are both doing! I'm just honest about it. You think the balance of evils mandates protecting speech. I think in cases of assaultive, racist, hateful expression there is no evil whatsoever associated with suppressing that speech. Are we at an impasse?

The best argument you have come up with for protecting racist speech is this hybrid of the marketplace of ideas, protection of dissent, and democratic self-government rationales. If that is the normative basis for protecting speech, it's easy to distinguish racist speech on those terms: The anti-war and anti-abortion protesters have a chance at being right. The war in Vietnam was a fiasco. I strongly support a woman's right to choose, but I have to admit to having some qualms about the morality of abortion. The anti-abortion protesters are obviously moved by sincere and deeply held ethical and religious beliefs, and we should allow those beliefs into public debate. Those kinds of dissenting voices ought to be heard because they contribute to the public conversation that ultimately results in a coherent account of the community's moral principles. We end up saying, "this is who we are," only after a long process of dialogue and contention in which numerous positions must be heard. That's why we allow protesters to burn flags despite the emotional harm experienced by veterans who put their lives on the line for what the flag symbolizes.

On the other hand, the book is closed on white supremacy and on the Nazis' racist ideology. There are two sides on many questions, including the rightness of sending troops to Vietnam and certainly on all the issues wrapped up in the abortion debate. But you can't tell me that there is a kernel of a serious political argument anywhere to be found on Hale's website or in the Nazi literature that Frank Collin wanted to distribute in Skokie. These guys are just attention-seeking wackos, but dangerous ones. Why not permit dissenting speech where reasonable people could disagree, but rule out of bounds speech that has no plausible foundation in truth, permissible expression of dissent, or democratic selfgovernment?

CL: Now it's you who are relying on arguments from skepticism! You can't bring yourself to say abortion is right, or at least acceptable. Instead, you make the standard pro-choice argument that abortion involves wrenching 
moral and theological decisions that should be left to individuals, not made by the state. That's fine, but notice that it is exactly the same as the civil libertarian position on speech. All we are saying is that people disagree about most issues of significance in our political, cultural, and social life, and for that reason the government should not declare some beliefs taboo. You realize, of course, that a committed pro-life activist would make the same argument about abortion as you make about racism-it's just flat-out wrong, so other kinds of rights can be limited by the government in the name of eliminating a positive moral evil.

NL: Abortion is currently contested in our society in a way that the belief in the Nazi program is not. If there is any one belief that is taboo in contemporary American society, it is the belief in white supremacy. Mari Matsuda argues that racist speech should be treated as a sui generis category to reflect its danger and utter lack of redeeming value. ${ }^{204}$ It is not something that people disagree about or something about which there can be a legitimate attempt to persuade. ${ }^{205}$

Where there is no reasonable debate about an issue, a state actor can take sides. That's why a state university could refuse to hire a Holocaust denier as a history professor, and it is why the Illinois committee was right to deny Matthew Hale's law license. The community has already established a moral story to account for its legal institutions, and the only way to add a new chapter to that story, to borrow Ronald Dworkin's metaphor, is to exclude racist speech from protection. ${ }^{206}$

CL: I take it, then, that you are arguing for a very narrow domain of unprotected speech. If the First Amendment loses its force whenever there is an issue that has only one side or where the community has unequivocally taken a position, what are we talking about excluding from public debate? Holocaust deniers, flat-earth theorists, and white supremacists. Anyone else?

NL: Yes. I would extend the regulation to expressions of male dominance, like pornography, and belief in heterosexual superiority, like anti-gay speech. These utterances do not contribute to the community's attempt to construct a coherent, attractive account of its fundamental moral principles. "Wrong opinions and practices gradually yield to fact and argument," Mill said ${ }^{207}$, and civil libertarians are forever preaching that the remedy for harmful speech is more speech. But there is a class of utterances that reveal beliefs which are extraordinarily resistant to persuasion,

204. Matsuda, supra note 11, at 2357.

205. Cf. David A. Strauss, Persuasion, Autonomy, and Freedom of Expression, 91 ColuM. L. REV. 334 (1991) (arguing that the government may not suppress speech on the ground that it may persuade someone to do something that the government considers harmful).

206. DWORKIN, LE, supra note 109, at 228-38.

207. Mill, supra note 138, at 23. 
and that is the category of statements of racial, gender, and other biases that are irrational and pernicious. There's no point opposing Hale's speech with more speech-he's simply not listening.

CL: Aha! You're not limiting censorship to expressions of beliefs on which the book is closed. Of course, you have to sweep broadly-otherwise your proposals have no practical effect. If courts permit incursions on the First Amendment only where speech by the lunatic fringe is at issue, maybe the damage to freedom of expression is lessened, but by definition the impact will be slight, since lunatic fringe speech isn't that much of a problem. What I worry about is what the military calls "mission creep." Limited interventions have a way of gradually morphing into full-scale commitments of ground troops. The same could happen here. The government starts by clamping down on the World Church of the Creator and NAMBLA ${ }^{208}$ and other groups with absolutely no reasonable message, and the next thing you know, officials target speech that makes them uncomfortable but which ought to be heard. Think of Rudy Giuliani again. It's anti-hate-speech precedents that give him the straightfaced argument against granting a permit to the Nation of Islam for the Million Youth March.

I've seen this happen at universities all the time. These antidiscrimination statements, hate-speech codes, diversity training sessions, and whatnot have a momentum of their own. Every interest group on campus wants to jump on the bandwagon and assert that they are traditionally disadvantaged and in need of protection. The next thing you know, we're tacking sexist, homophobic, ageist, and goodness knows what else onto the restrictions on racist speech. ${ }^{209}$ I agree with you that racism is an idea with no arguable merit, but some of these speech codes reach ideas that are much more debatable. Would a restriction on hostile speech that is directed at an individual on the basis of religion prohibit a vehement attack on the policies of the Sharon government in Israel? What about speech on the basis of disability? Would that prohibit a constitutional law professor from criticizing the Supreme Court's decision about the handicapped golfer? ${ }^{210}$ Could a college student be sanctioned for having a party in his apartment to watch the season finale of The So-

208. The North American Man-Boy Love Association, a favorite example for First Amendment professors to use on students who argue for absolute protection for all speech.

209. E.g., UWM Post v. Bd. of Regents, 774 F. Supp. 1163, 1165 (E.D. Wis. 1991) (quoting the University of Wisconsin's racial and discriminatory conduct policy, which regulates expressive behavior directed toward individuals on the basis of "race, sex, religion, color, creed, disability, sexual orientation, national origin, ancestry or age"); Nadine Strossen, Regulating Racist Speech on Campus: A Modest Proposal?, 1990 DUKE L.J. 484, 524 (quoting Stanford University's discriminatory harassment code that restricts certain expression based on an individual's "sex, race, color, handicap, religion, sexual orientation, or national or ethnic origin").

210. PGA Tour, Inc. v. Martin, 523 U.S. 661 (2001). 
pranos, a show that arguably perpetuates harmful anti-Italian-American stereotypes?

Let's get back to the silencing argument, though. I can think of plenty of utterances that might have the silencing effect you fear but which should be protected. I'll give you an example that came up in the litigation over the University of Michigan's hate-speech code. ${ }^{211}$ A graduate student in social work stated in class that he believed homosexuality was a disease that could be treated through counseling. He was brought up on charges of sexual orientation harassment on the grounds that he had engaged in speech that was intimidating and hostile.

NL: There are two possible responses to that incident. Mine is to say "hurrah" for the university. We all know that homosexuality is not a disease and that this graduate student was just a bigot. It was wrong for him to silence his classmates and thereby (ironically, because he appeals to the value of the marketplace of ideas) to stifle the free flow of discussion in the classroom. Everyone in the relevant discipline of social psychology or whatever knows that homosexuality is not a disease, so there is no more value in letting this jerk talk than there would be in giving a respectful hearing to a Holocaust denier in a history classroom. And if we could silence this guy in the classroom, then surely we could exclude that kind of speech from the legal system which is committed to certain fundamental truths, as embodied in the constitution.

The other response, the one you probably favor, is to admit frankly that the book may not be closed on these matters. The current science may be inconclusive on whether homosexual desire may be "cured"-or to use a less inflammatory term, altered-by counseling and therapy. Whether people ought to be subjected to that kind of therapy is a normative judgment that depends on our beliefs about sexuality, the family, privacy, and a host of other issues which are all contested in our society. The government, through its agents like state universities, should not step in and establish an authoritative view on these moral issues.

But because rights are not neutral, because they embody a particular vision of the good-one of free, detached, autonomous individuals-the second position is still a substantive moral one. It's just not a particularly attractive normative vision. I propose, on frankly policy grounds, rules for a better kind of society. Since either way it's a normative decision, why not be overt about the value judgments we both are making? ? $^{212}$

211. Doe v. Univ. of Mich., 721 F. Supp. 852, 865 (E.D. Mich. 1989).

212. Cf. Barry Friedman, The Counter-Majoritarian Problem and the Pathology of Constitutional Scholarship, 95 Nw. U. L. REV. 933, 935 (2001) (arguing that the problem of reconciling judicial review with democracy is a distraction from what ought to be the real agenda of legal scholarship, which is advancing normative arguments). See also Laurence H. Tribe, The Puzzling Persistence of Process-Based Constitutional Theories, 89 YALE L.J. 1063 (1980). 
Earlier I was making an argument by Dworkin (Ronald, not Andrea!) that our legal system is justified by a "scheme of principles," his idea that political legitimacy is ultimately a function of a coherent, attractive public narrative that makes the best possible interpretation of the community's practices. $^{213}$ The reason we suppress bigoted speech is that the fundamental value of racial equality is paramount in our constitutional system. The scheme of principles obviously contains protection for a great deal of speech, but it has to draw lines between acceptable and unacceptable utterances. And the only way to protect the countervailing value of equality is to declare certain points of view simply illegitimate. If we permit racist speech to exist on the assumption that there may be some value in it, we legitimate it. ${ }^{214}$ This is why the historian Deborah Lipstadt refuses to debate Holocaust deniers. ${ }^{215}$ If she were to go on a talk show with one of these bozos, it would imply that they have ideas worthy of being taken seriously, and that itself would be false.

\section{$\mathrm{X}$ \\ DiSAGREEMENT AT THE LEVEL OF POLITICAL THEORY}

CL: I remember that discussion. And all that talk about coherence and integrity and the "best possible constructive account of the community's institutions" made me want to reach for my checkbook and renew my ACLU membership immediately. (Or-and here is a weird turn of events-it made me think there might be something to law and economics, which is at pains to establish that individuals should be able to define well-being for themselves, without inference by the government. ${ }^{216}$ ) Deborah Lipstadt is free to do whatever she likes, but the government should not be empowered to decide that some ideas shouldn't be taken seriously.

NL: But don't you see, the government is already doing the same thing that Lipstadt is doing. It is declaring certain ideas out of bounds, but it is concealing that value judgment through doctrinal hocus-pocus, like the speech/conduct distinction. Also, the decision to give strong protection to speech is itself a political decision in the sense that it imagines a particular vision of the good for society. This talk about neutrality obscures the extent to which a government that gives Matthew Hale a trump card called a "right," that enables him to put up a hateful website despite all the harm it causes, is going to foster a public culture of individualism, public disengagement, alienation from sources of value, and conflict that

213. DWORKIN, LE, supra note 110, at 211, 243.

214. Gates, supra note 176, at 39-40 (citing Alexander Bickel).

215. Deborah E. Lipstadt, Denying the Holocaust: The Growing Assault on Truth AND MEMORY (1993).

216. Louis Kaplow \& Steven Shavell, Fairness Versus Welfare, 114 HARV. L. REV. 961, 980 (2001). 
is channeled into litigation over the assertion of rights. ${ }^{217}$ All I'm asking is for you to give me a substantive normative argument for that result.

CL: Once again, even though we disagree, we're on to something significant. You have pressed me to defend on the merits what Sir Isaiah Berlin refers to as negative liberty. ${ }^{218}$ Negative liberty is what a person has when he or she is left to do whatever he wishes without interference from others. ${ }^{219}$ Certainly it is true that the (negative) liberties asserted by different people will collide, and some of these asserted rights must be curtailed in the interests of peaceful coexistence, but there is nevertheless a core zone of freedom that may not be interfered with by the government for the sake of the public good. Positive liberty is a more elusive notion. For Berlin, it meant something like "being one's own master," so that the shape of one's life depends solely upon one's "true" self-being a rational, autonomous being as distinguished from a slave to one's animal nature or passions. ${ }^{220}$ This by itself is not problematic; of course, some degree of positive liberty is necessary to leading a good life. The danger in relying too much on a conception of freedom as positive liberty is that it may be taken to follow from the separation of a person into higher and lower selves that a collective entity - a state, a tribe, a race, a churchmay coerce people into following some goal that they ostensibly would endorse if they could only free themselves from the domination of their lower natures. ${ }^{221}$

I tend to agree with Judge Posner that the Constitution is "a charter of negative rather than positive liberties." ${ }^{222}$ The significance of that distinction is that the government cannot enforce regulations that are aimed at removing barriers to individuals who wish to realize a particular way of life or vision of the good, such as racial equality. The new left is on the side of a positive conception of liberty, of a broad sphere of government authority to place restraints on individual action in the name of realizing a better life. The most prominent theorists in your camp admit as much: "What is ultimately at stake in this debate is our vision for this society.",223 Similarly, the crusade against pornography has been animated by the desire to enable women to be in control of their bodies and the political

217. E.g., MARY ANn GLENDON, Rights TALK: THE IMPOVERISHMENT OF POLITICAL Discourse (1991); Michael J. SANDEl, DEMOCRACY'S DisCONTENT: AMERICA IN SEARCH OF A Public Philosophy (1996); CHARLES TAYLOR, SOURCES OF THE SELF (1986).

218. BERLIN, supra note 20, at 194.

219. Id.

220. Id. at 203-05.

221. See also Isaiah Berlin, The Pursuit of the Ideal, in THE CROOKED TIMBER OF HumAnity 1 (Henry Hardy ed., 1990).

222. Bohen v. City of East Chicago, 799 F.2d 1180, 1189-90 (7th Cir. 1986) (Posner, J., concurring).

223. Mari J. Matsuda et al., Words that Wound: Critical Race TheOry, Assaultive SPEECH, AND THE FIRST AMENDMENT 15 (1993). 
construction of their worth as human beings, rather than consigning them to the lower status of objects of male fantasies. ${ }^{224}$

As an abstract proposition, enhancing the ability of people to govern themselves sounds unobjectionable. The political implications of that position are what I find troublesome. A government that wishes to enhance individuals' ability to realize their true potential must, of course, be in the business of defining "true," genuine, or authentically good ways of life. Again with the law-and-economics crowd, I think the government ought to be protecting the liberty of people to do what they regard as valuable, not guiding us in the direction of some hypothetical good life that is different from the object of anyone's actual concern. ${ }^{225}$

NL: I see the point of your negative and positive liberty distinction, but as long as you're going to invoke Berlin, it only seems fair to point out that his arguments for preferring negative to positive liberty have struck many people as unconvincing. ${ }^{226}$ One problem is internal to Berlin's distinction. He prefers negative liberty because there is no single common human nature that is universal, toward which we all aspire. Thus, it follows that there is no basis in some higher value for restraining individuals from living their lives as they see fit. But if that is so, then the same critique can be turned against a political system which rests on so-called negative liberty. Any decision to accommodate the competing liberty-claims of individuals will itself be an evaluative judgment, and if there is no common human nature upon which to ground this judgment, then it is just as illegitimate as any other political decision that is justified by enhancing the positive liberty of individuals. Once again, we cannot avoid normative arguments about substantive moral visions or conceptions of the good. Berlin says these conceptions of value are incommensurable, but then he doesn't offer a very satisfying account of choosing among incommensurables.

CL: Of course, there are many such arguments that could be offered. You could make a consequentialist argument, claiming that negative liberty is necessary for the accomplishment of something else that is an acknowledged good, like the discovery of truth, in the context of expressive liberties. This is not exactly Berlin's position, but many other liberal political philosophers have made arguments like this. As Mill puts it, for example, you could argue that a "hands-off" attitude by the government toward ideas is necessary to create a vigorous intellectual environment, where people are free to try out new, possibly heterodox ideas. ${ }^{227}$ Or, to use another one of Mill's arguments, you can argue for permitting ideas you

224. DwORKIN, FL, supra note 132, at 219-20 (summarizing Catharine MacKinnon's argument).

225. See Kaplow \& Shavell, supra note 216, at 1340.

226. See, e.g., JOHN GRAY, ISAIAH BERLIN 21-37 (1996).

227. Mill, supra note 138, at 36 . 
disagree with to flourish on the grounds that you need to understand them, and study them carefully, in order to be better able to refute them. ${ }^{228}$

NL: But Mill says the distinction between truth and falsehood is that truth can withstand attempts to suppress it, rising again and again until eventually in an enlightened time it is recognized as such. ${ }^{229}$ Are you really arguing that we need to protect bigoted speech because, for all we know, in the future white supremacism may turn out to be true? Or that the nonconforming opinion, here hate speech, contains part of the truth that it shares with the received opinions? ? $^{230}$ I don't think you want to go there. As for the argument that I need to understand hate speech in order to refute it, I don't see what there is to understand. Bigots think that people unlike them are inferior. There's no idea there-it's just a visceral hatred-so there can be no benefit to the quality of debate from paying close attention to those statements. What's the point in "throwing myself into the mental position" of Matthew Hale? I know what's in his mindhate and evil. I understand it perfectly well already; I don't need his website to help me. The marketplace of ideas has never struck me as a good argument for protecting something like hate speech that isn't the assertion of a claim to truthfulness. It would be like arguing that you should protect professional wrestling because it might lead to the discovery of truth! Hate speech is an assault, not a contribution to public debate.

CL: I don't need to claim that hate speech is likely to be true. Mill also recognizes what contemporary theorists call the "chilling effect" argument. Even if bigoted speech has no value as a step on the road to discovery of truth, if we fail to protect that kind of expression we risk casting a pall over the whole metaphorical marketplace of ideas. Other speakers whose ideas may be unpopular may be deterred from participating in public debate by the fear that their ideas might be deemed heretical. "Who can compute what the world loses in the multitude of promising intellects combined with timid characters, who dare not follow out any bold, vigorous, independent train of thought, lest it should land them in something which would admit of being considered irreligious or immoral?" "231 No one would call people like Louis Farrakhan or Leonard Jeffries "timid," but you can imagine someone less bold, but having similar ideas, who would be driven from the marketplace of ideas by the threat of government penalties for hate speech. Just remember what

228. Id. at 38-39.

229. Id. at 31.

230. See id. at 47.

231. Id. at 35 . 
Southern state governments tried to do to Thurgood Marshall and the NAACP during the civil rights movement.

The significance of Mill's "partial truth" argument is that even pretty nasty speech may contain a germ of truth, and it ought to be protected for that reason. Alternatively, some utterances you may wish to classify as hate speech may nevertheless be valuable because they expose the pomposity, self-righteousness, or hypocrisy of political or academic elites, or because they satirize prevailing attitudes and beliefs. And you can combine this argument with the chilling effect argument and observe that it can be difficult to distinguish between legitimate commentary and satire, delivered in an effectively biting form, and valueless "hate speech." Think of the controversy over the rap group 2 Live Crew. Their lyrics are always being denounced as misogynist, and maybe they are, but the group responds that they are just parodying mainstream rap, or maybe producing a reductio ad absurdum of their fellow rappers. (If that example makes me sound dated, you can use the more recent case of Eminem, who says his anti-gay and misogynist lyrics are also intended parodically.) Do you want government officials making decisions about whether a particular music recording is valuable?

But let's take another tack. You can also make nonconsequentialist arguments for the protection of speech. Another argument for negative liberty is that autonomy has intrinsic value. "[T]he freedom to do what one wants, or to make choices, is valuable for its own sake." ${ }^{232}$

NL: I've heard that argument so many times I've lost count. The thing that continues to trouble me about it, though, is that I don't see a value to autonomy that permits people to make bad choices. What on earth is valuable in Matthew Hale's freedom to be a bigot? I'll give you an example I borrowed from David Luban. ${ }^{233}$ Suppose a guy named George has a beautiful cherry tree on his land. It is a local landmark. People come from miles around to look at his tree, and a photo of it even graced the cover of the phone book. One day, George buys an axe. He decides he is going to test out his axe by chopping down the cherry tree. $\mathrm{He}$ doesn't need the land the cherry tree is standing on for any purpose, he just wants to have a few whacks at a tree with his axe. So, he chops down the tree. We know he had political autonomy to do it-no one is arguing that the local government should interfere with his right to do what he chooses with his tree in this case-but I want you to tell me, what is good or valuable about George's autonomy in that case?

232. Christopher L. Eisgruber, Civic Virtue and the Limits of Constitutionalism, 69 FORDHAM L. REV. 2131 (2001).

233. David Luban, Two Discourses on Human Dignity (unpublished manuscript, on file with author). 
CL: Well, I suppose negative liberty can also be defended as a necessary precondition for an individual's development of her own natural endowments without which it is impossible to pursue other ends. ${ }^{234}$

NL: Apply that argument to the cherry tree example. How does it benefit George to give him space to decide to chop down the tree? He has learned nothing as a result, except perhaps that he doesn't really enjoy chopping down trees. He is not developing his natural faculties or pursuing a substantive vision of the good life-he's just idling away time, ruining natural beauty for others, and in no way becoming a more fully realized human being. I think something similar is true of the hatespeech cases. The core zone of freedom you would give to bigots does not enable them to develop as persons; rather, it just enables the waste of something valuable, with a concomitant interference with the interests of others.

CL: For autonomy to be meaningful, it must permit people to make bad choices as well as good. Unless you want to be a neo-Aristotelian and argue that only good choices are valuable, you have to allow people space to choose unwisely. Otherwise they do not have the opportunity to be truly the authors of their own lives. ${ }^{235}$

I could also argue that the good in the George case is simply the absence of government interference. Let me give you a negative argument for negative liberty. I don't have to maintain the thesis that autonomy has intrinsic value, provided I can convince you that it's a bad thing to give government the power to interfere with peoples' decisions about how to live their lives. Why would it be bad? First, because we think the government is tempted to abuse this power, or to exercise it to the detriment of disfavored groups who, because of their numerical size or the history of discrimination against them, are unable to force the government to respect their interests.

Aryeh Neier makes the latter argument in his book on the Skokie case. ${ }^{236}$ He observes that the only "alternative to freedom is power," and that Jews can be safe only in societies in which restraints are placed on power. ${ }^{237}$ He goes on, in a moving passage:

The restraints that matter most to me are those which ensure that I cannot be squashed by power, unnoticed by the rest of the world. If I am in danger, I want to cry out to my fellow Jews and to all those I may be able to enlist as my allies. I want to appeal to the world's sense of justice. I want restraints which prohibit those in power from interfering with my right to speak, my right to publish, or my right to gather with others who also feel threatened. Those in power must

234. BERLIN, supra note 20, at 196.

235. GRAY, supra note 226, at 30-32 (describing Berlin's position).

236. NEIER, supra note 68 , at 4.

237. Id. 
not be allowed to prevent us from assembling and joining our voices together so we can speak louder and make sure that we are heard. ${ }^{23}$

In other words, Neier is on the side of negative liberty because governments which seek to enforce some kind of positive vision of human good can too easily abuse their power.

NL: Again, that is a purely strategic argument, and it is based on assumptions that may not stand up to empirical scrutiny. You think the danger of government abuse of power is a greater evil than the enduring bigotry that people of color must suffer.

You're right that progressive constitutional theorists have in mind a vision of the good for society. This is an important point to emphasize. Robin West, for example, reads the Equal Protection Clause as a charter of positive liberty. ${ }^{239}$ The Fourteenth Amendment demands substantive equality, not merely the kind of formal equality parodied by Anatole France's quip that the laws of France prohibit the rich as well as the poor from sleeping under bridges. ${ }^{240}$ In the context of expression, equality means not resting content with reassuring marginalized groups that they have the same formal liberties as their rich, majority-race, male peers, but undertaking to correct systematically for dysfunctions in the marketplace of ideas that unfairly skew public discourse in favor of the powerful.

In the end, we're doing the same thing. Despite your protests to the contrary, you are asserting a normative vision too. It seems as though the one thing we can agree upon is that First Amendment issues invariably resolve into constructive moral arguments; there is no such thing as a neutral, value-free standpoint from which the competing positions can be assessed.

$$
* * *
$$

That, in any event, is my view. It does not follow that the new left position is the correct one. It may very well be the case that we should prefer the civil libertarian's proposal to leave hateful expression unregulated for substantive moral and political reasons. But I do think the new left theorists deserve a great deal of credit for relentlessly demanding a normative justification from the civil libertarians for the welter of constitutional rules that are implicated in a case like the Hale bar-admissions controversy. The state action doctrine, the speech/conduct distinction, the right/privilege distinction, the principle of content- and viewpoint-neutrality, the Barnette/Gertz notion that there is no such thing as a false idea or government-identified heresy, the clear and present dan-

238. Id. at 4-5.

239. Robin West, Progressive Constitutionalism: Reconstructing the Fourteenth AMENDMENT 114-18 (1994).

240. "The law, in its majestic equality, forbids the rich as well as the poor to sleep under bridges, to beg in the streets, and to steal bread.” ANATOLE FrANCE, THE RED LILY (1894). 
ger test, and the rule that emotional harms are insufficiently weighty state interests to justify regulation, are all a familiar part of First Amendment discourse. Thanks to the new left critics, their familiarity no longer insulates them from the requirement of a normative foundation.

On the other hand, the new left argument that racial equality is a fundamental constitutional value on a par with the freedom of speech seems difficult to contain within principled boundaries. Particularly if a court takes seriously the argument that private bigotry and state action together contribute to the social construction of racial or gender inferority, a wide range of expression may be susceptible to regulation. Susan Gellman gives the example of the story of Cinderella that perpetuates a view of women as helpless, passive, and dependent upon rescue by powerful men. ${ }^{241}$ Surely this story contributes to a cultural environment that is oppressive to women, yet no one would seriously suggest that it should be regulated, directly or indirectly. What should be the principled distinction between an applicant for the bar who has written a story similar to Cinderella and Matthew Hale? Various members of the new left have suggested distinctions, sometimes involving an element of mens rea, such as an intent to demean a particular person on account of race or sex, ${ }^{242}$ or a tendency to provoke immediate violent response, ${ }^{243}$ which would presumably not apply to Cinderella, Eminem records, or Chris Rock monologues. As civil libertarians have frequently observed, however, the relatively narrow boundaries accepted by new left critics, which are necessary to enable courts to make principled distinctions of the kind suggested here, tend to minimize the impact of hate-speech regulations on the problem of societal racism and gender inequality. And if the restrictions are cabined by some principle other than the constitutional value of equality, it is hard to see how they are justified on that basis. In other words, if only "fighting words" are regulated, then it appears that the regulation is aimed at preventing violence, not at vindicating the fundamental value of equality. If that is true, then either equality is merely a makeweight or the regulation's facial justification (preventing violence or emotional injury resulting from face-toface insults) is a stalking horse for some other project, such as a comprehensive rebalancing of equality and expressive liberties. This is the concern that animates the civil libertarians.

Whether the classic civil libertarian position will continue to command the respect of courts, as it did in cases like R.A.V., ${ }^{244}$ or whether more courts and government agencies will accept the invitation of the critics and decide cases on a more explicitly evaluative basis, and so balance equality interests against ex-

241. Gellman, supra note 23, at 372. See also DWORKIN, FL, supra note 132, at 220, 227-28 (noting that pornography probably contributes substantially less to the subordination of women than television and other mass media portrayals of women).

242. Delgado, Words, supra note 137, at 179.

243. Lawrence, supra note 12, at 450-54; Thomas C. Grey, Civil Rights v. Civil Liberties: The Case of Discriminatory Verbal Harassment, 8 SOC. PHIL. \& POL'Y 81 (1991).

244. See also Iota Xi Chapter of Sigma Chi Fraternity v. George Mason Univ., 993 F.2d 386, 392-93 (4th Cir. 1993). 
pressive liberties, is the question bequeathed to the new millennium by the hate speech debate. The answer to that question depends on some deeply contested jurisprudential premises. Progress on the hate speech debate can be made only by keeping in mind the grounds for deeming a judicial decision legitimatewhether a decision to restrict the asserted expressive freedom of someone like Hale must be based solely in the text of the constitution and the intent of the Founders, ${ }^{245}$ constructive interpretation of the "scheme of principles" that gives moral worth to our legal system, or whether judges should decide cases in a way that properly expresses the relevant underlying moral values. ${ }^{246}$ In general, the academic discussion of hate speech has avoided the armchair empiricism, parade-of-horribles arguments, and accusations of racism or Big Brother-ism that sometimes characterize the debate in the popular media, of which Henry Louis Gates has said: "The strongest argument for regulating hate speech is the unreflective stupidity of most of the arguments you hear on the other side." 247 The legacy of the hate-speech debate and the new left attack on the standard civil libertarian picture, therefore, is a rich literature on constitutional jurisprudence that may not provide a definitive answer in any given case, but which at least points the way to a satisfying way to frame the conversation. We cannot ask for any more from theory.

245. DWORKIN, LE, supra note 110.

246. Pildes \& Anderson, supra note 107.

247. Gates, supra note 176, at 18. 